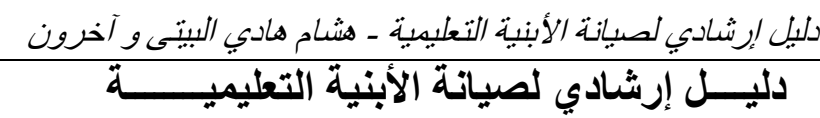

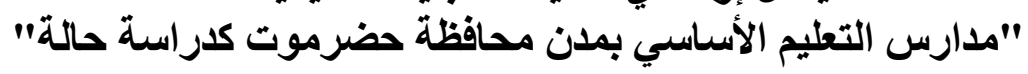 \\ م.هشام هادي البيتي* أ.د.مجدي محمد رضوان أ.د. محمد عبد السميع عيد د. ممدوح علي يوسف

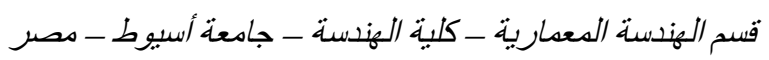 \\ تاريخ الورود 4 نوفمبر 2012 ، تاريخ القبول 29 ديسمبر 2012
}

الملخـــ: 20

تتعرض الأبنية التعليمية بمدن محافظة حضرموت بـاليمن إلى العديد من المشكلات نتيجة لتهالك مكوناتها

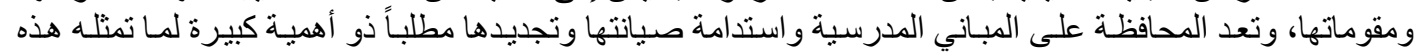

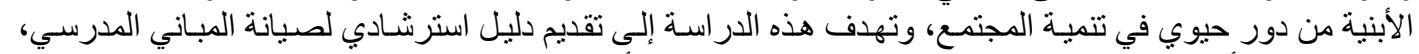

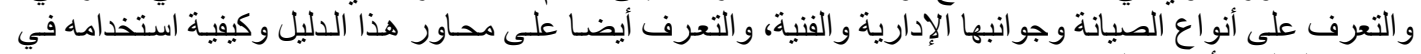

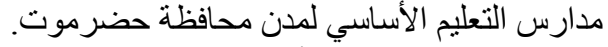
وتتناول الدر اسنة النقاط الآتية:

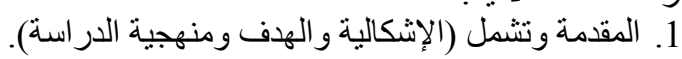

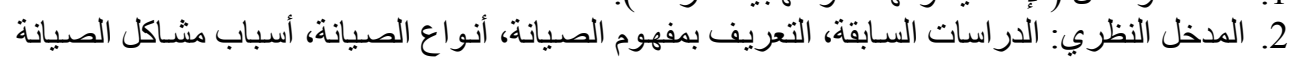

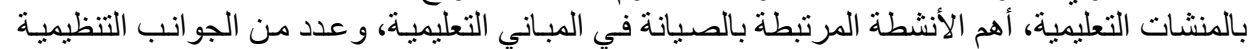

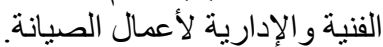

3. دليل إرشـادي لأعمـال الصيانة في الإنية المباني المدرسية (هدف وأطر اف ومحاور الدليل المقترح لصيانة

المباني المدرسية وكيفية استخدامه). 4. النتائج و التوصيات.

\section{1. المقدمـــة : وتثشمل (الإشكالية، الهـف، منهجية الدراسة) 1 1. 1 ـ العقدمة}

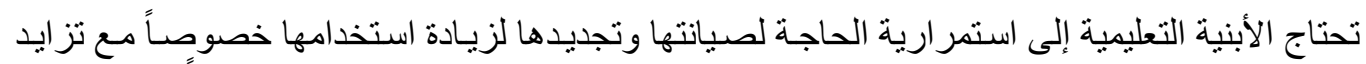

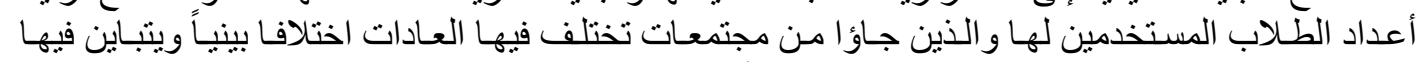

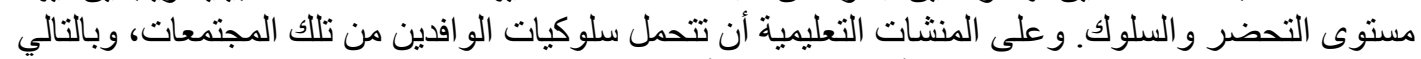

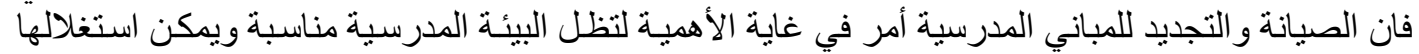

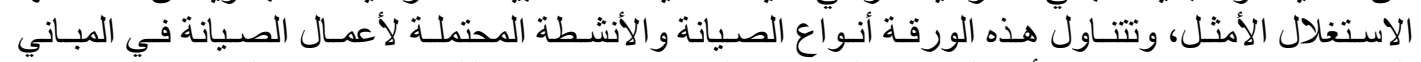

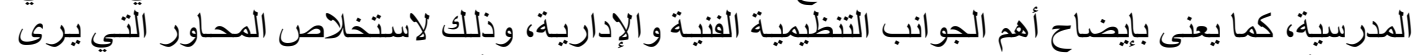

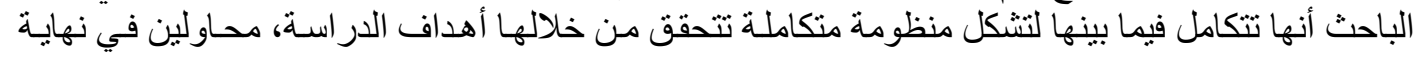

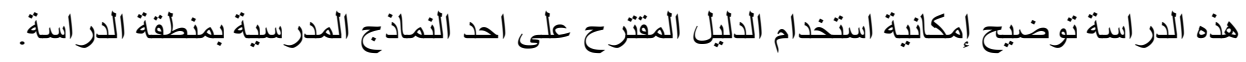

$$
\text { 2.1 إثكاليبة الدراسة: }
$$

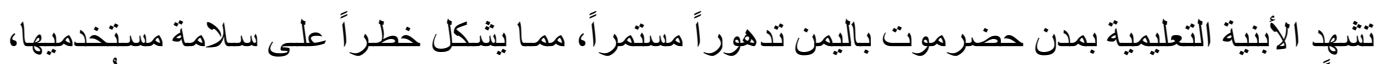

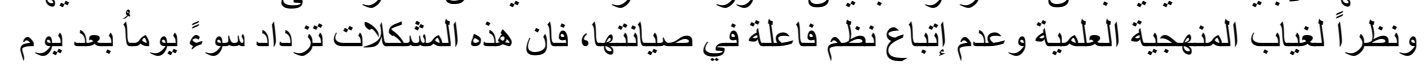

Journal of Engineering Sciences, Assiut University, Faculty of Engineering, Vol. 41, No. 3, pp. 1212 - 1237, May, 2013, E-mail address: jes@aun.edu.eg 


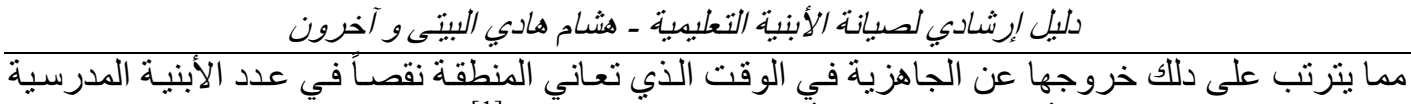

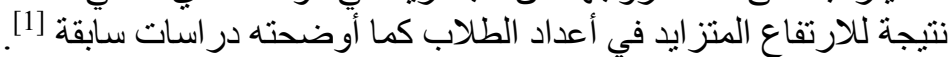

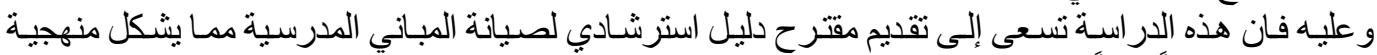

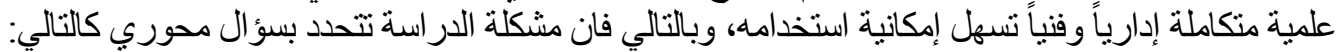

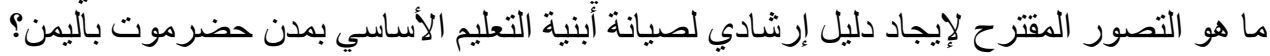

$$
\text { 3.1 } 3.1
$$

هدف البحث بصورة رئيسية إلى تقديم دليل إرشـادي لصيانة المباني المدرسية يرتكز على مجمو عـة من

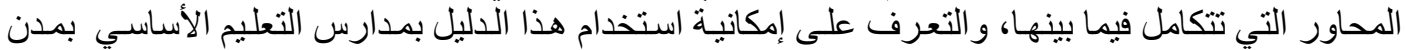
محافظة حضرموت لتفادي المشكلات في الأبنية التعليمية الناتجة عن فينة غياب الصيان الصيانة.

$$
\text { ( } 4.1
$$

تتحدد منهجية البحث من خلال المحاور الآتية:

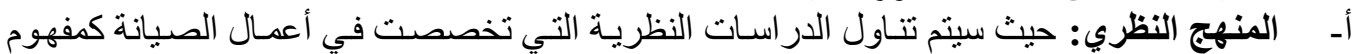

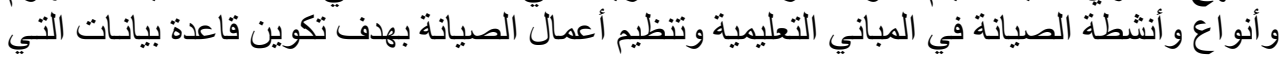

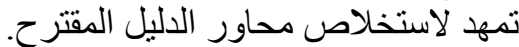

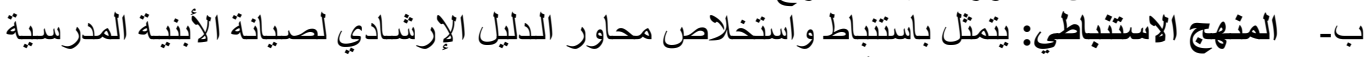

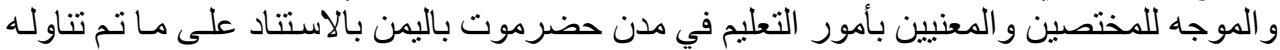
في الدر اسة النظرية.

2. المدخل النظري

يشمل المدخل النظري : أهم الدر اسات السابقة التي تناولت موضو ع الصيانة وجدولتها ومفهومها و أنو اعها

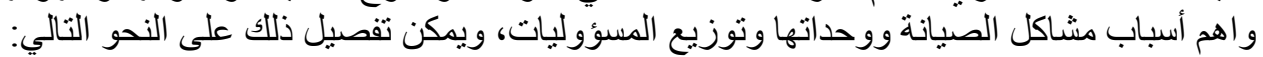

$$
\text { الدابقات السابقة } 1.2
$$

تناول الاليل الخاص بالصياتة والصادر عن هيئة الأبنية التعليمية بمصر [1]: عدداً من المفردات التيات التعريفية

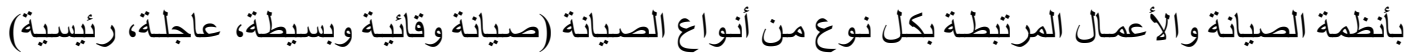

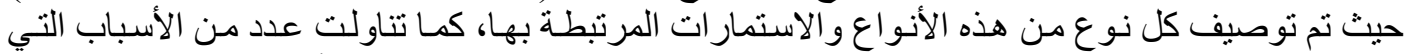

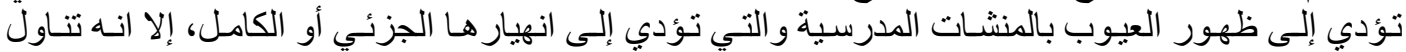
الصيانة بصورة السى طرور وصفية.

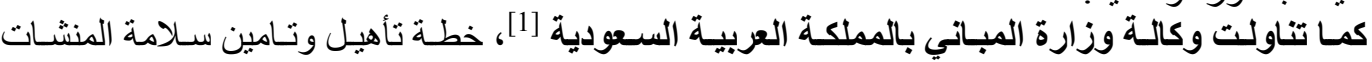

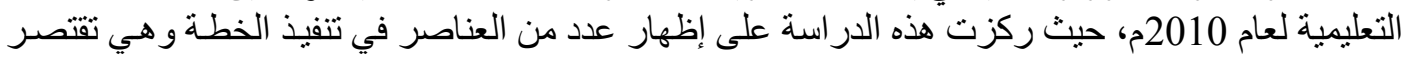

[1] البيتي، هشـام هـادي، دراسـة تحليليـة عن تصميم مبـاني التعليم الأساسـي بالمدن اليمنيـة "مدينـة المكلا كدراسـة حالـة ،رسـالة

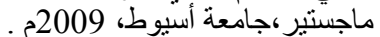

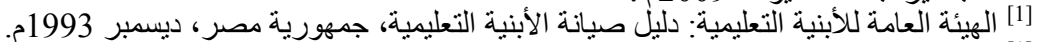

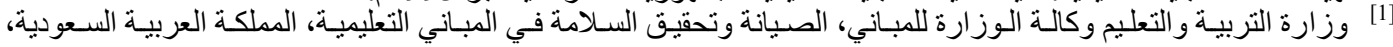

Journal of Engineering Sciences, Assiut University, Faculty of Engineering, Vol. 41, No. 3, pp. 1212 - 1237, May,2013,E-mail address: jes@aun.edu.eg 


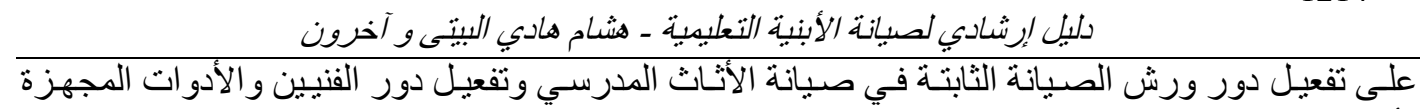

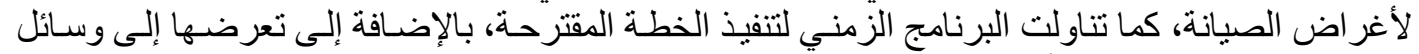

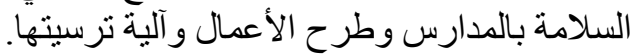

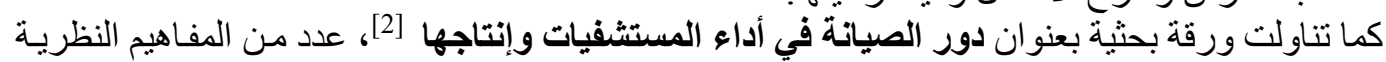

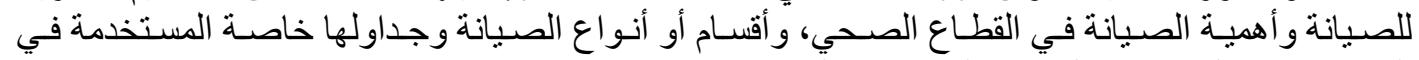

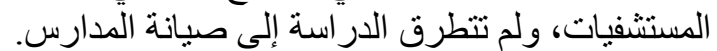

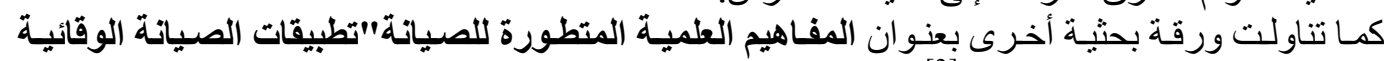

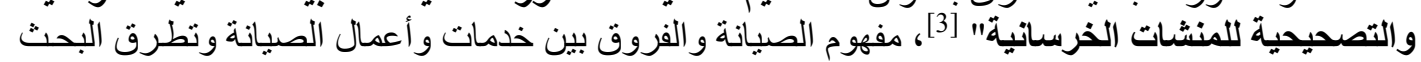

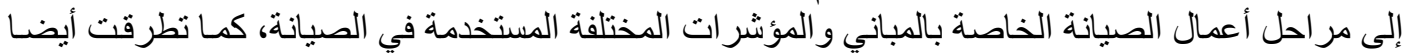

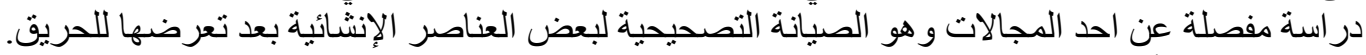

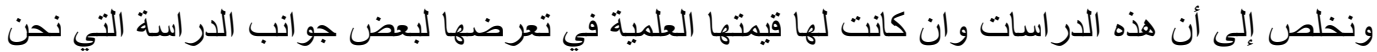

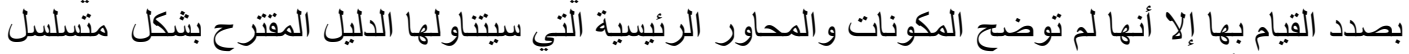

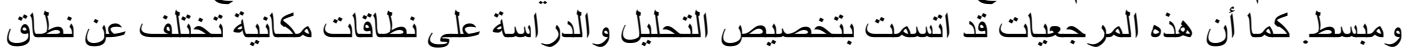
الدر اسة المستهدفة بهذا الدليل، و لا توجد در اسات تناولت صيانة المباني المدرسية بمحافظة حضرموت.

$$
2.2
$$

تعرف اللجنة الأمريكية صيانة المباني [4] بالاتي:

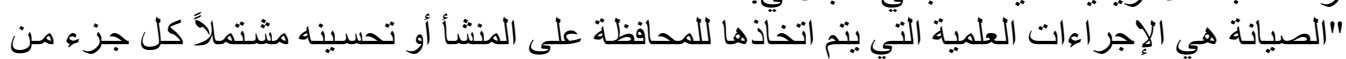

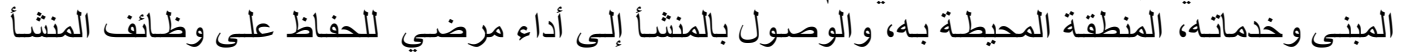

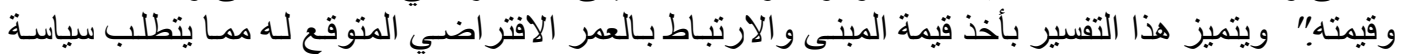

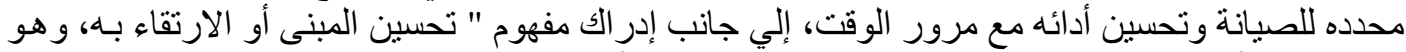

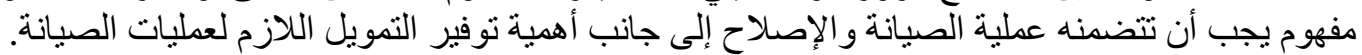

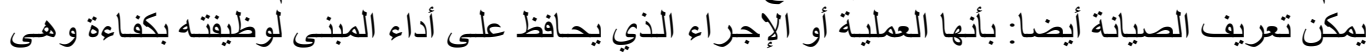

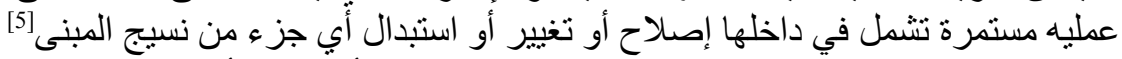

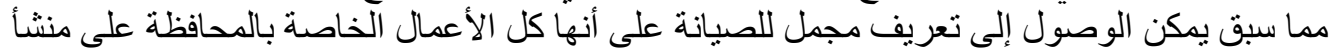

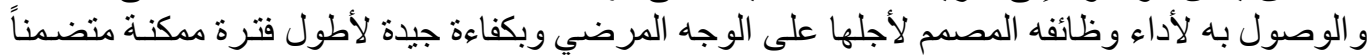

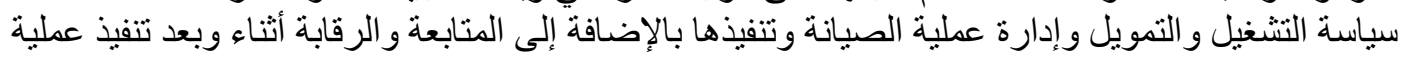

وييرز الدور المهم لعمليات الصيانة في تحقيق الآتي [1]:

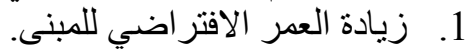

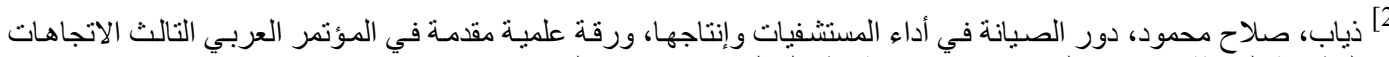

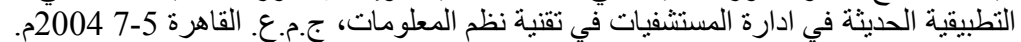

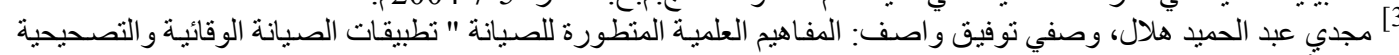

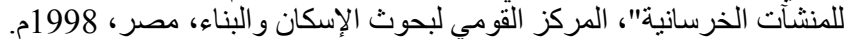

${ }^{[4]}$ Barrie chanter \& peter swallow , Building maintenance manage ment, Blackwell science, oxford, London 1996. P.2

${ }^{[5]}$ Mohmoud M.Idris, Some Factores affecting Maintenance of Building in U.F.E, Technical article, Alarn Albena, issue 83,P.4

Journal of Engineering Sciences, Assiut University, Faculty of Engineering, Vol. 41, No. 3, pp. 1212 - 1237, May, 2013, E-mail address: jes@aun.edu.eg 
2.

3.

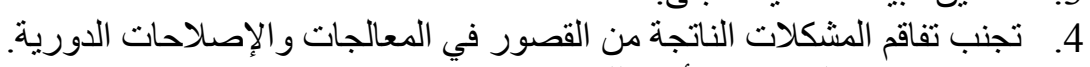
5.

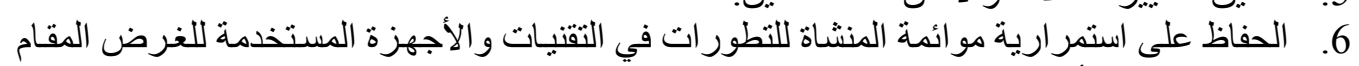

من اجلها هذه الأبنية.

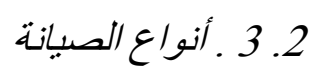

تصنف أعمال الصيانة إلى الأنو اع[2] التالية:

1.3 .3

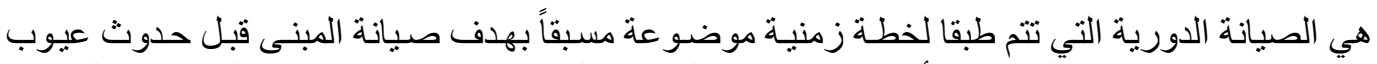

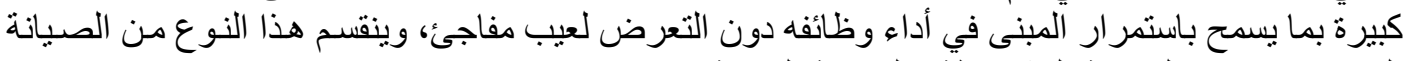

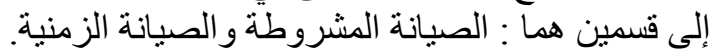

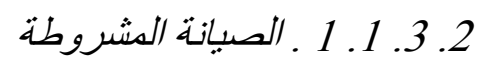

هي الصبانـة المرتبطـة بشـرط معلوم كأن يصل التدهـور لعناصـر المبنـى إلى حــ معين تم تحديده مسـبقا.

$$
\text { 2. } 2.1 \text {. } 2 \text { ـ الصبيانة الزمنية }
$$

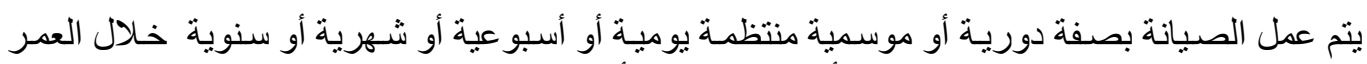

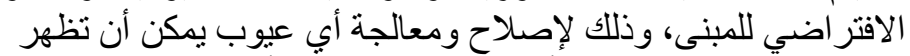

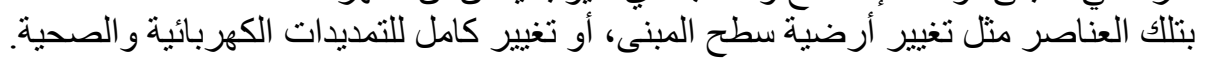

$$
\text { 2.2. } 2.3
$$

و هي الصيانة التي يتم من خلالها إجر اءات التصليح فوراً وبدون أي خطة مسبقة لتجنب حدوث مزيداً من الإشكالات و الأعطال.

3.3 .3

هي تللك التي تم فيها إصلاح العناصر أو المعدات عند تعطيلها أو الشعور بأن هناك خلاً معيناً قد يحدث.

$$
4.2 \text { ـ أسباب مشاكل الصبانتة بالمنشات التعلبيبة }
$$

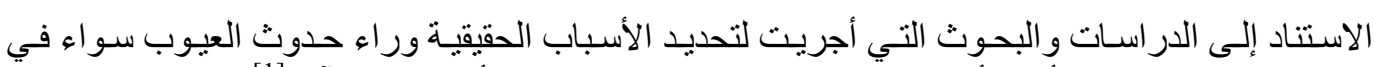

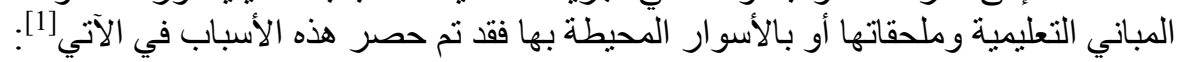

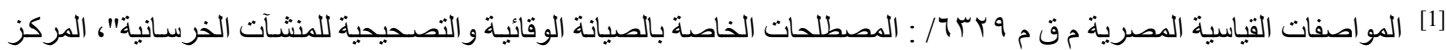

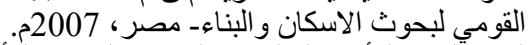

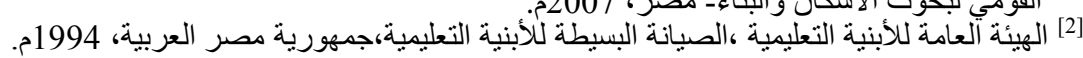

${ }^{[1]}$ Terry Wireman و Preventive Maintenance و Virginia Reston Pub. Co. - 1984

Journal of Engineering Sciences, Assiut University, Faculty of Engineering, Vol. 41, No. 3, pp. 1212 - 1237, May, 2013, E-mail address: jes@aun.edu.eg 


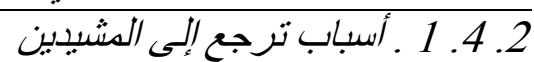

أ- ق قصور في دراسات التربة.

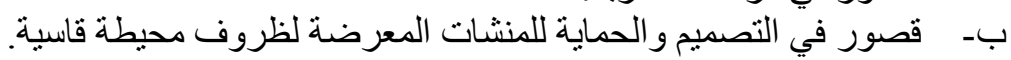
ج- قصور في المو اد المستخدمة في البناء.

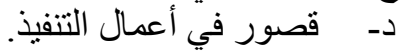
ولقد تـم التغلب على هذه الأسباب بصدور كودات ممارسـة، و هي قو انين هندسية تتحكم في التصميم و التشييد و أعمال التفتيش وكذلك مو اصفات قياسية لضمان مناسبة مو اد الَبناء للأعمال التي ستستخدم فيها.

$$
\begin{aligned}
& 2 \text {. } 2 \text {. } 2 \text { ـ أسباب ترجع إلى المستخدمبن } \\
& \text { أـ ـ قصور في الصيانة. } \\
& \text { ب- ت تعليات غير مدروسة. }
\end{aligned}
$$

ج- تغير ات غير مدروسة سواء اء في الاستخدام أو تغير ات في العناصر الإنشائية.

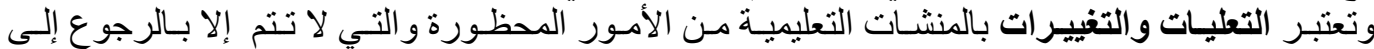

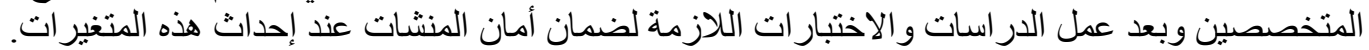

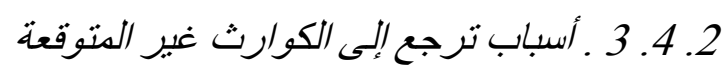

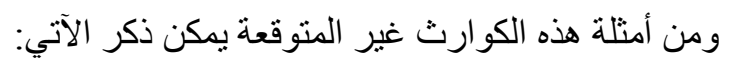

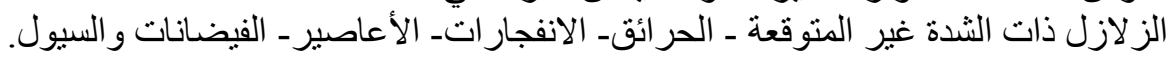

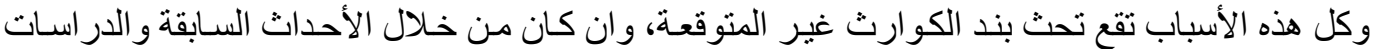

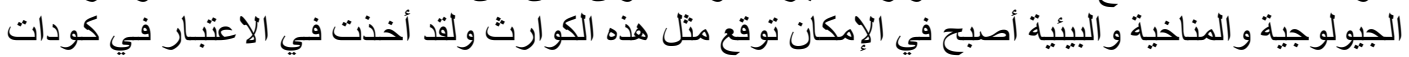

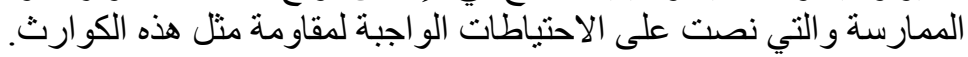

$$
\text { } 5.2 \text { ـوحدات الصيانة في الأبنية التعلبيبة }
$$

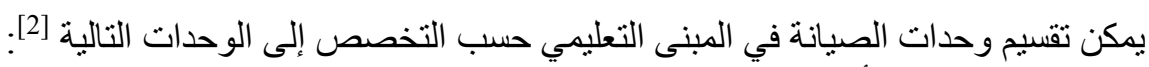

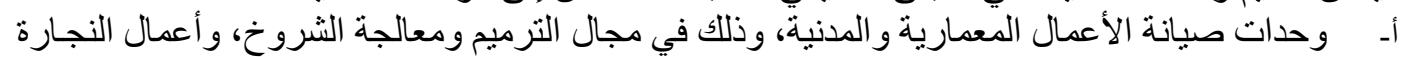

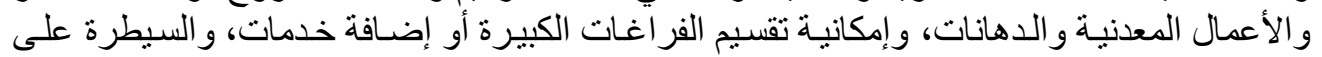

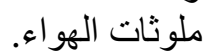
بـ وحدات صيانة الأعمال الكهربائية، الميكانيكية، و الكهروميكانيكية، و المصاعد ومكيفات الهو اءو و المـاء

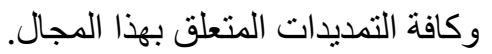

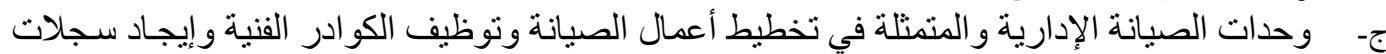

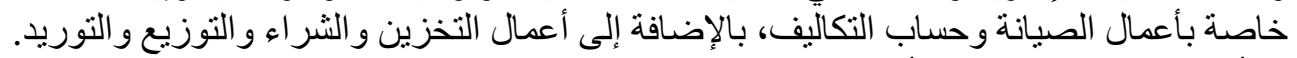

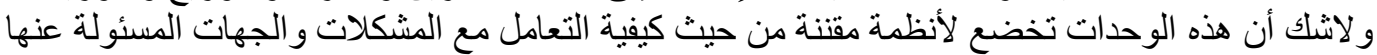

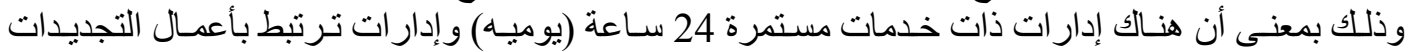
و المقاو لات التي تكون اكبر من قدرة إدارة الددرسة ويشملها جميعا الإدارة الهندسية المركزية.

[2] الهيئة العامة للأبنية التعليمية ،الصيانة البسبطة للابنية التعليمبة، جمهورية مصر العربية، 1994م. Journal of Engineering Sciences, Assiut University, Faculty of Engineering, Vol. 41, No. 3, pp. 1212 - 1237, May, 2013, E-mail address: jes@aun.edu.eg 


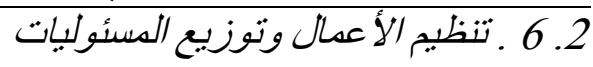

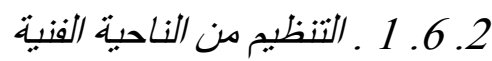

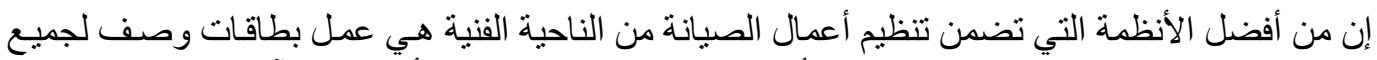

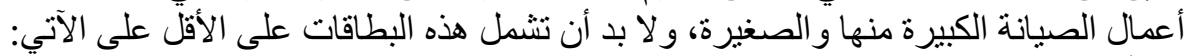

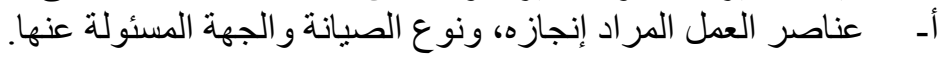

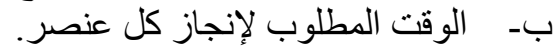

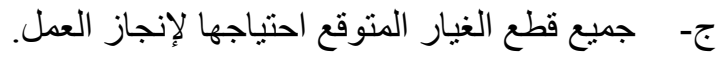

6.2. 2 . التنظبي من الناحبية الإدارية

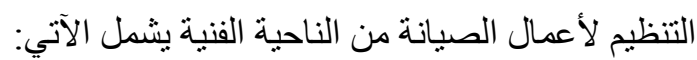

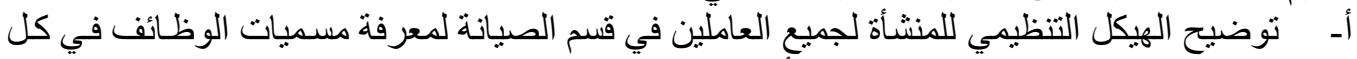

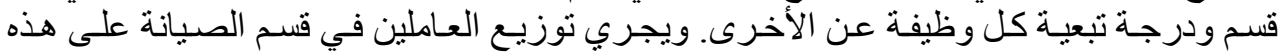

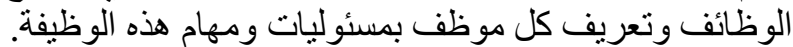

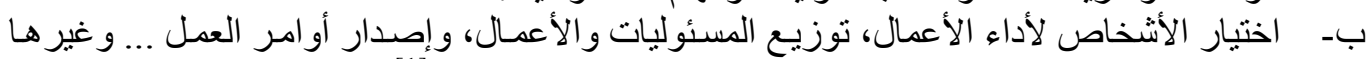

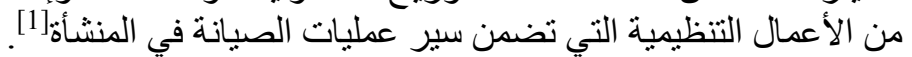

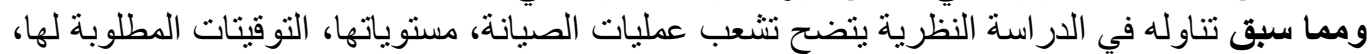

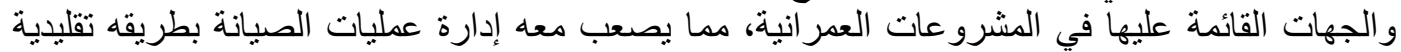

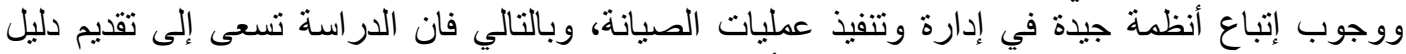
لتحسين إدارة الصيانة بالمباني المدرسية، كما سيأني معنا.

\section{3. دليل إرشادي مقترح لأعمال الصيانة في المباني المدرسية

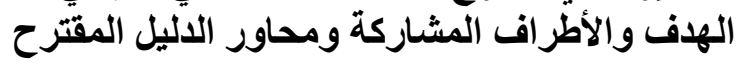
1.3

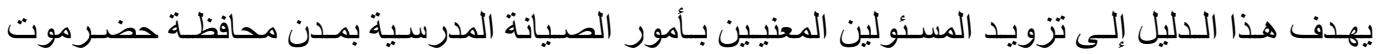

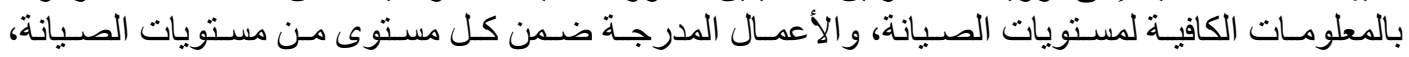
و البرنامج الزمني لتنفيذ أعمال الصيانة وفق جدولة محددة بحيث لا تؤثر على سير العملية التعليمية.

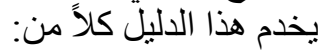

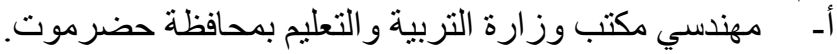

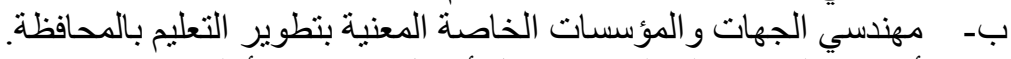

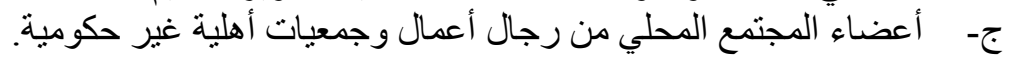

[1] شريف محمد صبرى العطار ، صبيانة المبانى مدخل لإدارة وتخطيط أعمال صيانة المباني ، رسـالة ماجستير، كلية الهندسة جامعة القاهرة .1996. 111م.

Journal of Engineering Sciences, Assiut University, Faculty of Engineering, Vol. 41, No. 3, pp. 1212 - 1237, May, 2013,E-mail address: jes@aun.edu.eg 


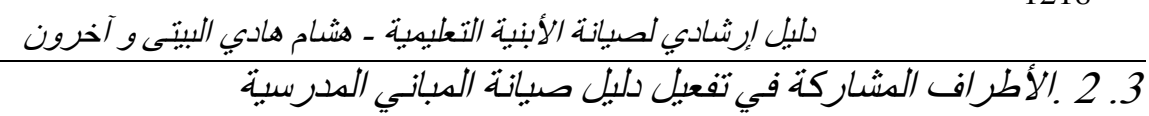

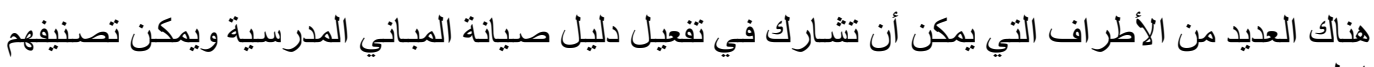

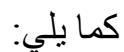
الأجهزة الحكومية: والتي تتحمل مسئولية وضع المعايير التصميمية وتامين التوعية اللازمـة بأهمية تطوير

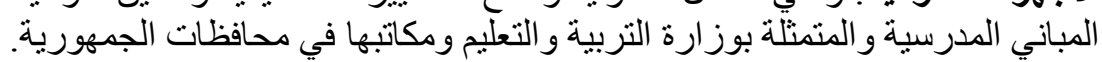

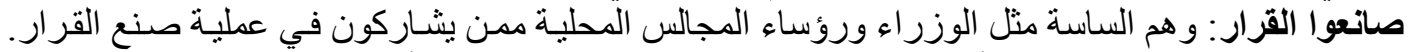

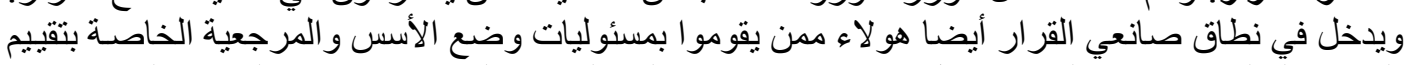

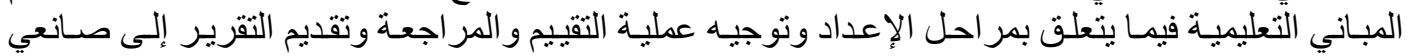

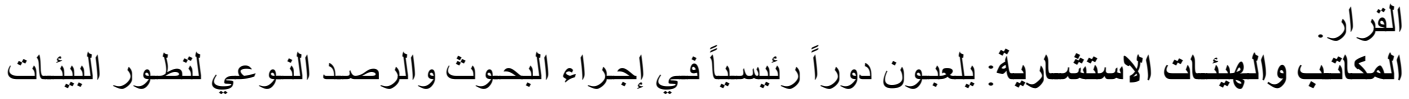

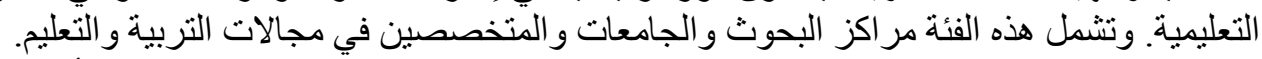

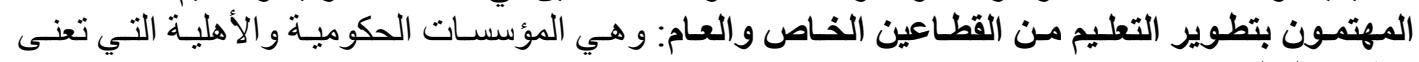

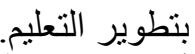
أطر افت العملية التعليمية: و هم مستخدمي البيئات التعليمية من معلمين وطلاب و إدارة مدرسية.

$$
\text { 2.3. } 1 \text { ـ النتائج المتوقعة من الأطراف المشاركة }
$$

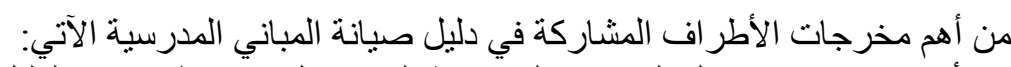

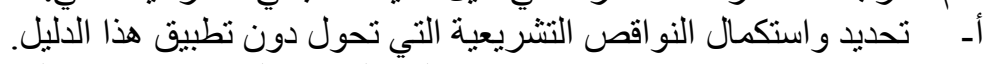

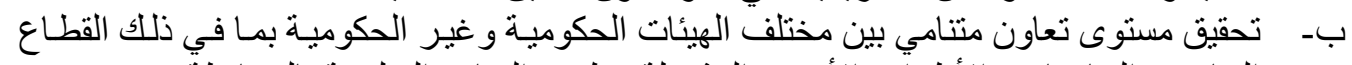

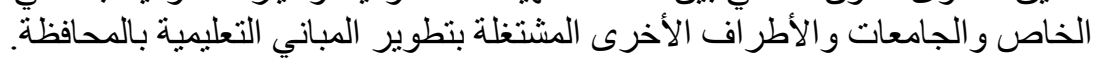

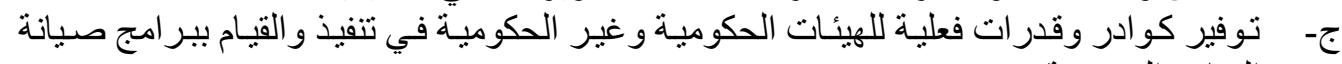
المباني المدرسية.

$$
\text { 3-3 3 3حاور الدليل المقترح: }
$$

يتكون الدليل المقتر حمن عدد من المحاور بدءا بتحديد مظاهر مشـاكل الصيانة و انتهاءً بعرض لآلية تنفيذ أعمال الصيانة. ويوضح النشكل رقم (1) محاور الدليل المقتر ح لصيانة المباني المدرسية [1]

[1] ${ }^{[1]}$

Journal of Engineering Sciences, Assiut University, Faculty of Engineering, Vol. 41, No. 3, pp. 1212 - 1237, May,2013,E-mail address: jes@aun.edu.eg 
دليل إرشادي لصبانة الأبنية التعلبية ـ هشام هادي البيتى و آخرون

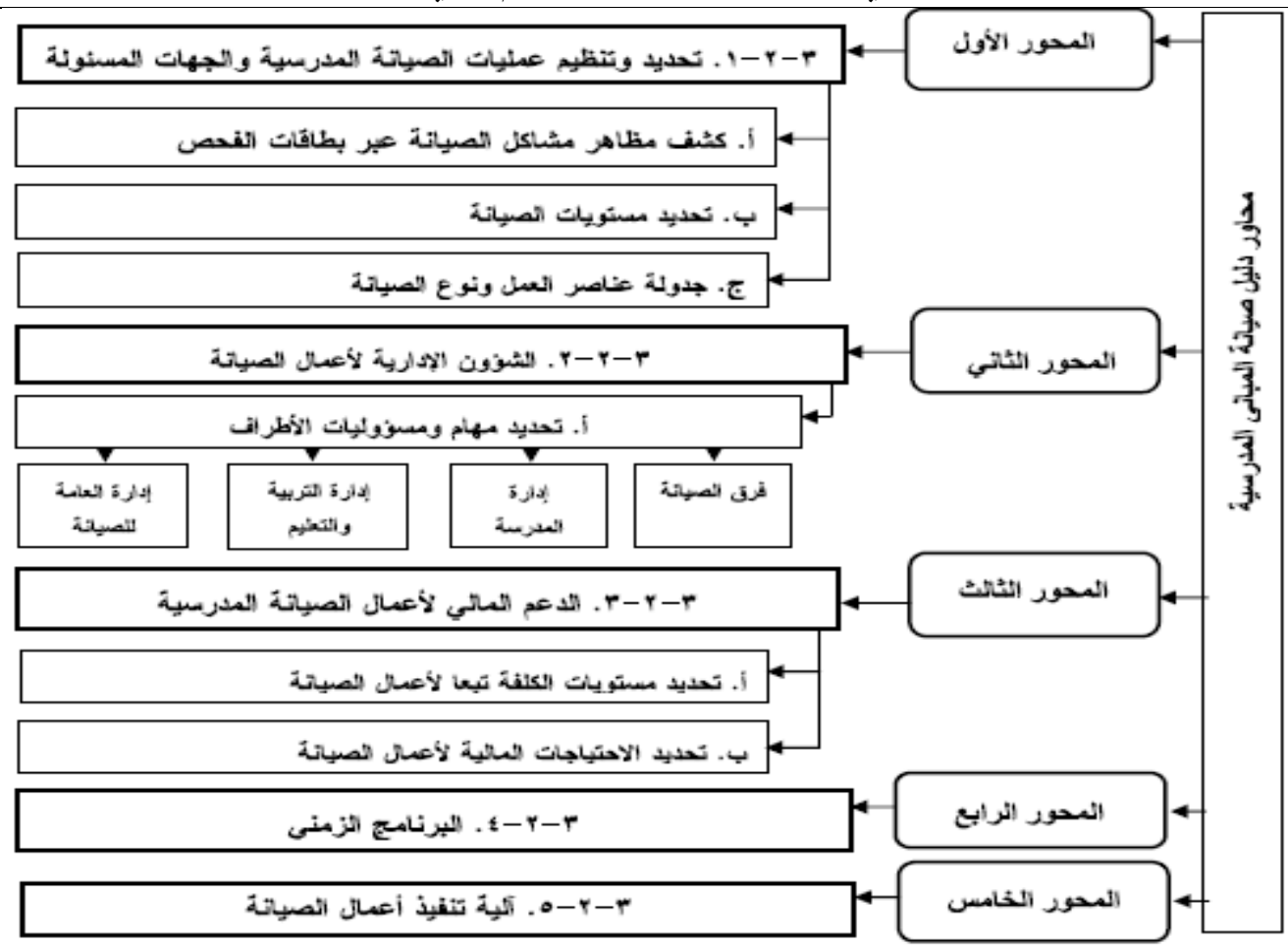

شكل رقم (1): الهيكل التظيمي لمحاور دليل الصيانة المدرسية

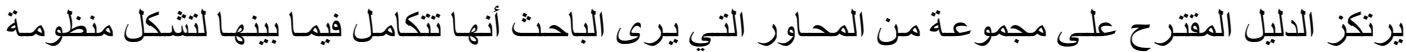

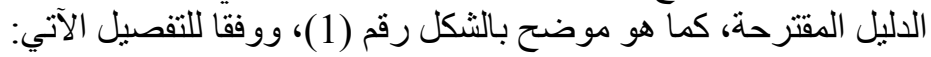

3. 3. 1 ـ المحور الأول. تحدبي وتنظبم عدلبات الصبانة المدرسبة والجهات المسئولة عنها

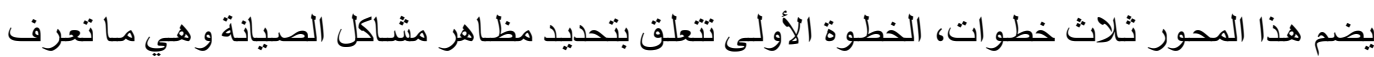

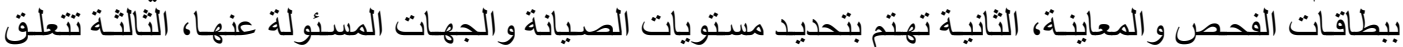
بجدولة وتصنيف لأعمال الصيانة، وفق التفصيل التصان الآتي:

$$
\text { 3.3. } 1 \text { ـ } 1 \text { ـ تحديب مظاهر مشاكل الصبانتة (بطاقات المعابنة) }
$$

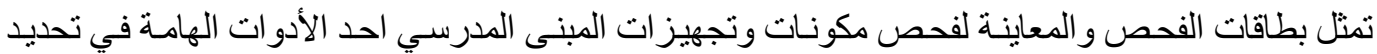

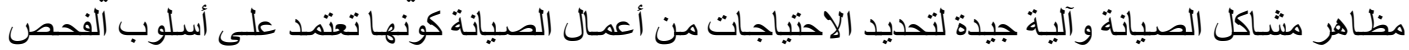

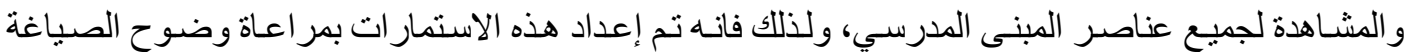

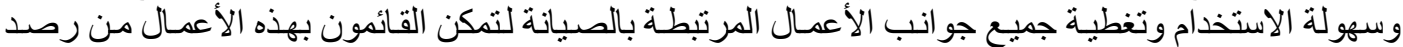
جميع العيوب التي قد تظهر بالمبنى المدرسي، وقد تم تقسيم هذه البطاقات إلى عدد من الاستمار ات وفنق الآني: الآني:

Journal of Engineering Sciences, Assiut University, Faculty of Engineering, Vol. 41, No. 3, pp. 1212 - 1237, May, 2013,E-mail address: jes@aun.edu.eg 


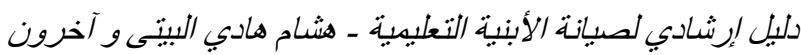

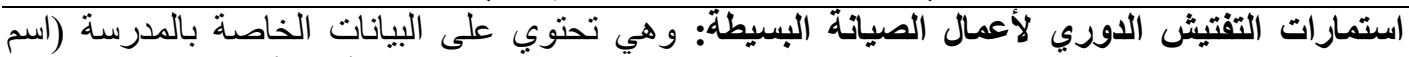

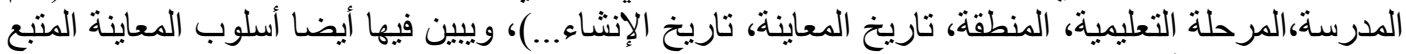

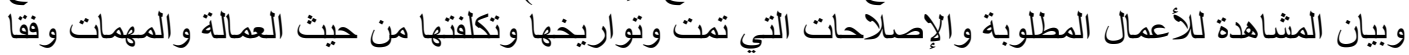

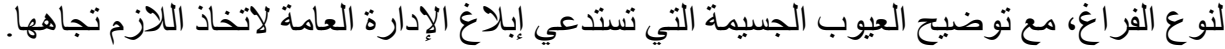
استمارات بيان ومتابعة أعمال الصيانة العاجلة: سيتم الاستعانة بما أعدته هيئة الأبنية التعليمية فقد عمدت

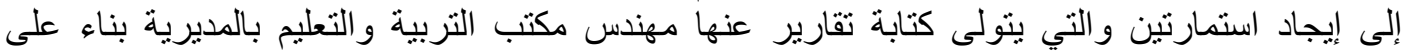
الخطاب الموجه من قبل مدير المبنى المدرسي، ويتم تدوين الأعمال المطلوبة وفئ وفقا للاتي:

استمارة الأعمال الصحية: ويسجل بها عيوب خطوط الصرف والتغذية والغاز وخزانات المياه والأجهزة الصحية وشبكات الحريق و أيه عناصر أخرى، مع التوصيف الدقيق لنولية النية العمل ورقم الفراغ. استمارة الأعمال الكهربائية: ويدون بها الأعطال واستبدال خطوط الكهرباء التالفة واستبدال القواطع بلوحات

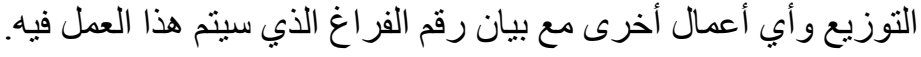

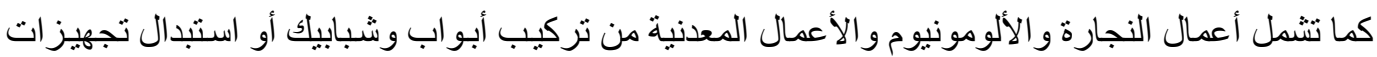
مدرسية أو إصلاحها وأيه أعمال أخرى مع بيان رقم الفراغ أغ الذي سيتم فيه هذا العمل.

\section{2. 2 . 2 ـ تحدبي مستويات الصبانة المدرسبية والجهات المسئولة عنها}

تعنى هذه الخطوة بتوضيح مستويات الصيانة المدرسية و الجهات المسئولة عنها وفق التفصيل الآتي:

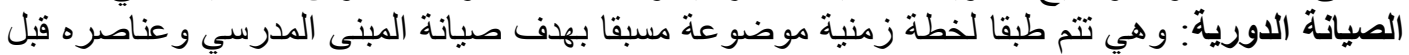

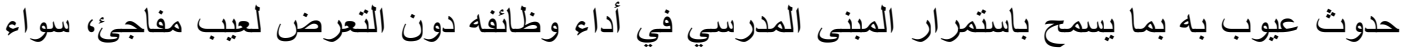

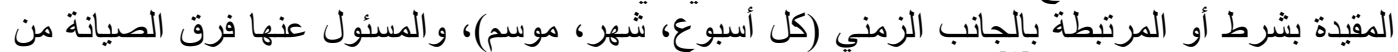
الفنبين بإدارة التربية و التعليم [1]

الصيانة البسيطة (المتابعة اليومية): وهي تتم من خلال التفتيش اليومي في حالة المبنى والأعمال التكميلية

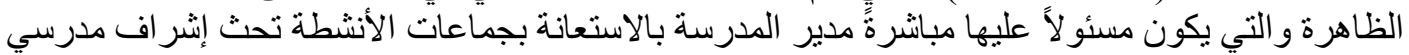

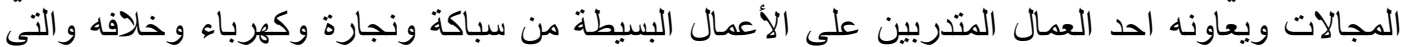

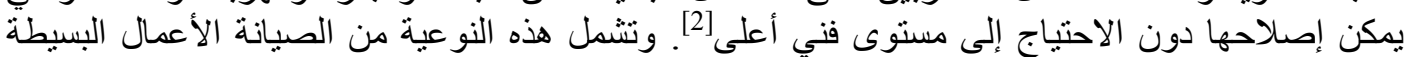
الآتية:

(أعمال السباكة، أعمال النجارة، أعمال الدهانات، أعمال الكهرباء، بعض الأعمال المتفرقة مثل زراعة

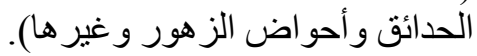

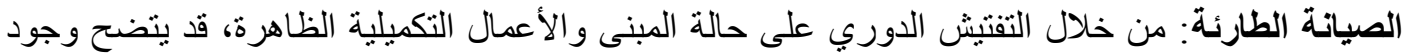

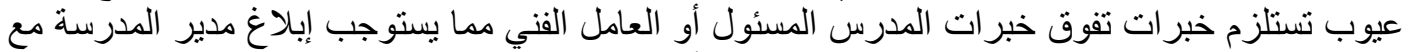

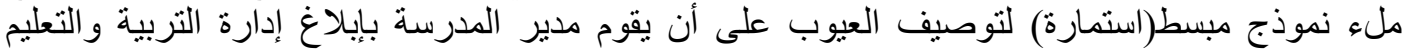

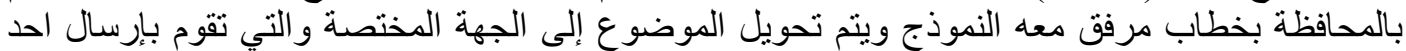

[1] المو اصفات القياسية المصرية (م ق م 9 צr 7 ) :المصطلحات الخاصة بالصيانة الوقائية والتصحيحية للمنشآت الخرسانية"،

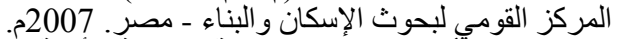

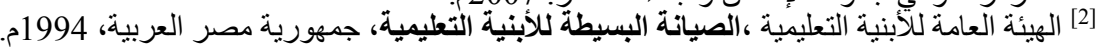

Journal of Engineering Sciences, Assiut University, Faculty of Engineering, Vol. 41, No. 3, pp. 1212 -1237, May, 2013,E-mail address: jes@aun.edu.eg 
دلبل إرشادي لصيانة الأبنية التعليمية ـ هشام هادي البيتى و آخرون

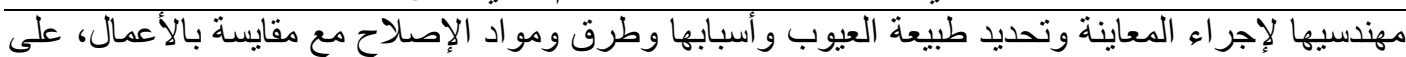

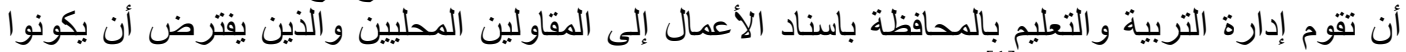

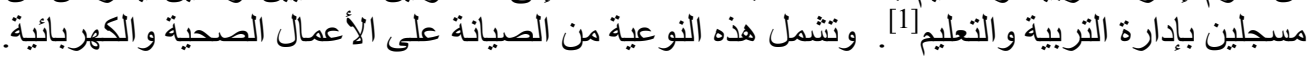

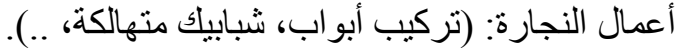

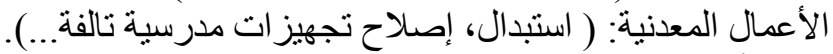

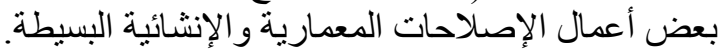

الصيانة الرئيسية: في إطار الخطة المتكاملة للصيانة للإدارة العامة للصيانة، فانه على مديري إدارة التربية

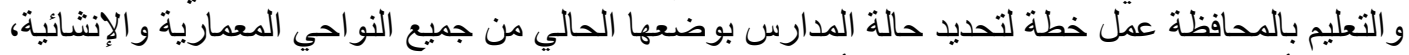

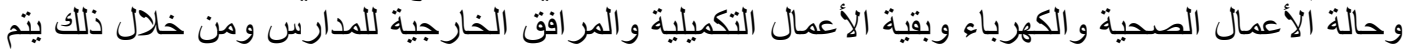

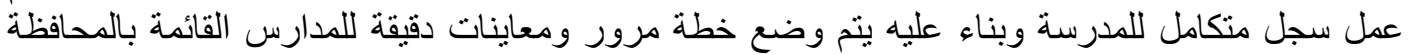

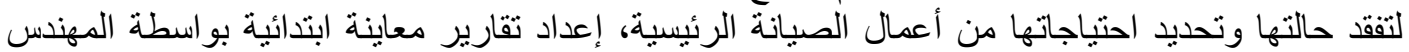

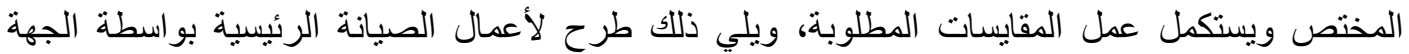
المختصة على الثركات و المقاولين المتخصصين في إجر اء هذه النوعية من الصيانة.

3. 1 3. 3 ـ جدولة لنوع العهل وعناصر العهل ونوع الصبانة والجهة المسئولة عنها

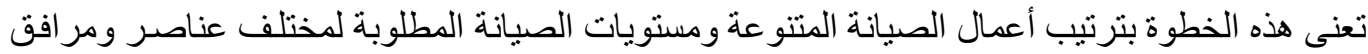
مبنى المدرسة حسب طبيعتها و الجهات المسئولة عن تتفيذها وفق المئ البيان الأتي:

جدول رقم (21-3): نوع العمل ومفردات العناصر و أنواع الصيانة و الجهات المسئولة عنها [2]

\begin{tabular}{|c|c|c|c|c|c|}
\hline \multicolumn{3}{|c|}{ الجهة المسئولة عن تنفيذها } & \multirow[b]{2}{*}{ 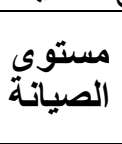 } & \multirow[b]{2}{*}{ عناصر ومفردات العناصر } & \multirow[b]{2}{*}{ 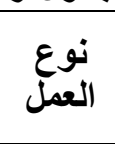 } \\
\hline والمشياريعة الميع & بالإدارة & المدرسة إدارة & & & \\
\hline & $\checkmark$ & & طارئة & 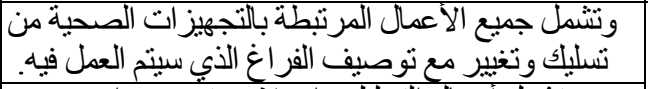 & \multirow{2}{*}{ 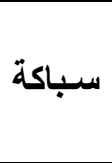 } \\
\hline & $\checkmark$ & & طارئة & وتشمل اعمال التسليك و إصلاح و تغيير مواسير & \\
\hline & & $\checkmark$ & بسيطة & 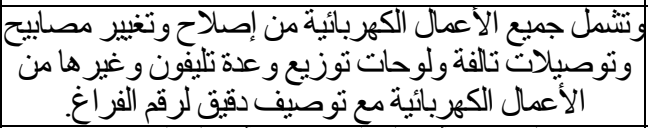 & كهرباء \\
\hline & & $\checkmark$ & طارئة & 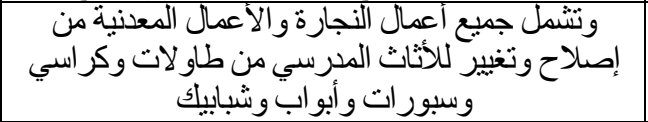 & 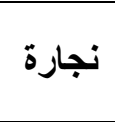 \\
\hline & $\checkmark$ & & طارئة & 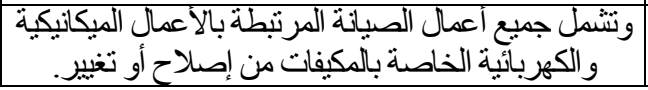 & تكييف \\
\hline
\end{tabular}

[1] [الهيئة العامة للأبنية التعليمية ، الصيانة البسبطة للأبنية التعليمية، مرجع سابق.

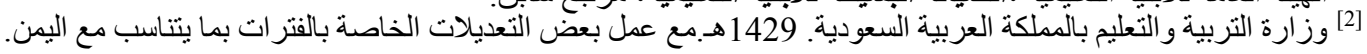

Journal of Engineering Sciences, Assiut University, Faculty of Engineering, Vol. 41, No. 3, pp. 1212 - 1237, May, 2013, E-mail address: jes@aun.edu.eg 


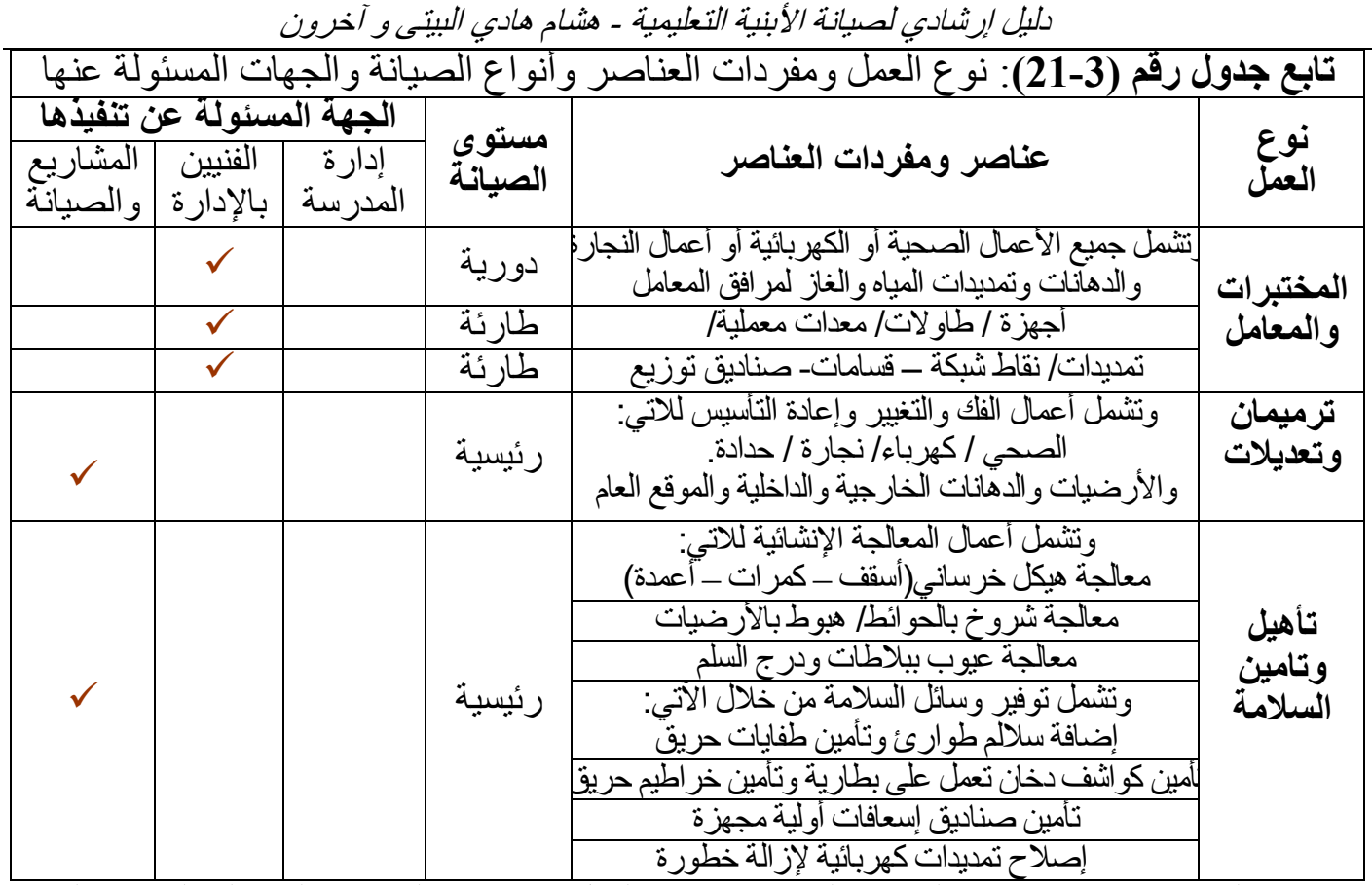

تم في السابق تحديد مستويات الصيانة المدرسية ونوع العمل ومفردات العناصة العناصر التفصيلية لصيانة المباني

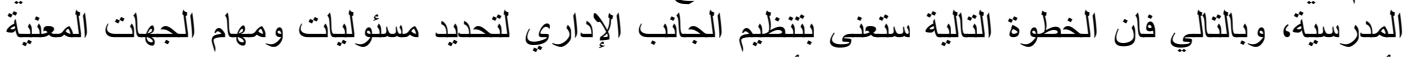

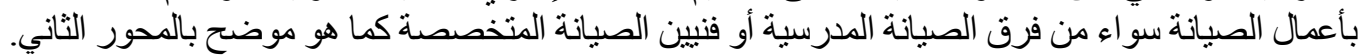

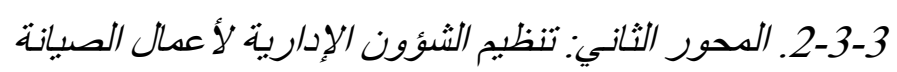

يعنى هذا المحور بتوضيح مهام ومسئوليات الإطراف المعنية بأعمال الصيانة، وفق التقصيل الآتي:

$$
\text { 1-2-3-3 . تنظبم الأعمال ومعرفة مهام ومسؤوليات الأطراف الإدارية لئية }
$$

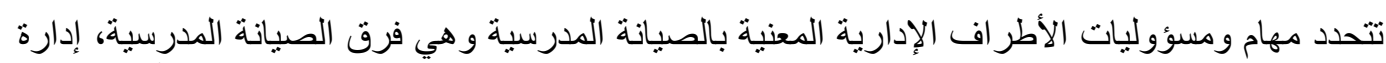

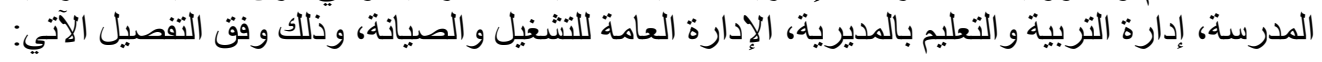

$$
\text { مهام فرق الصيانة المدرسبية }
$$

1. المشاركة في نظافة وصيانة المدرسة و الحفاظ على سلامتها.

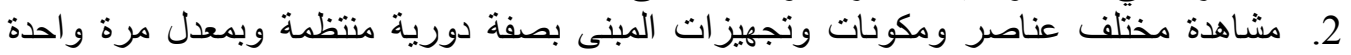

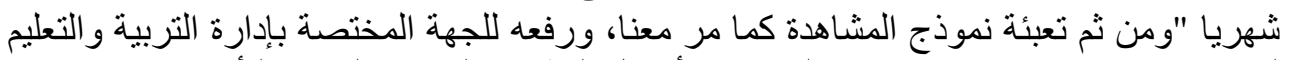

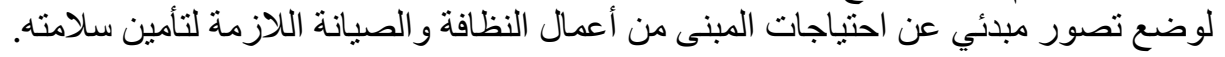

\section{مهام ومسؤوليات إدارة المدرسة}

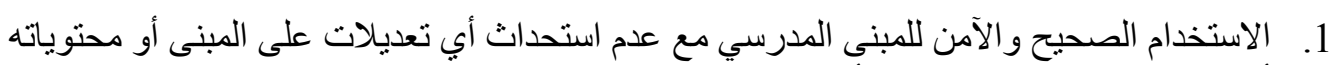
أو بالتمديدات الكهربائية إلا بعد أخذ مو افقة الجهة المختصة بإدارة التربية و التعليج.

Journal of Engineering Sciences, Assiut University, Faculty of Engineering, Vol. 41, No. 3, pp. 1212 - 1237, May, 2013, E-mail address: jes@aun.edu.eg 


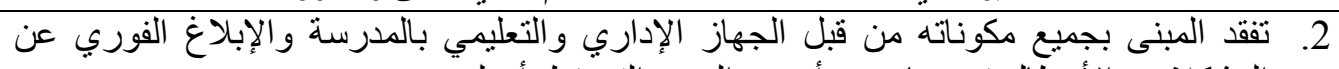

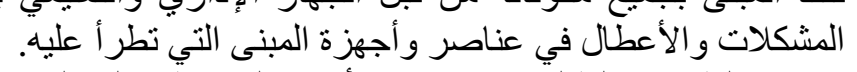

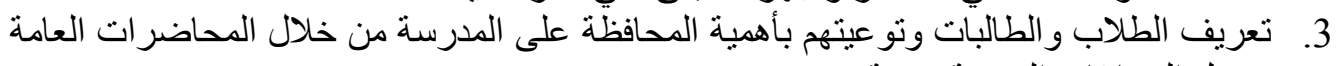
و عمل المسابقات الدورية بصفة البات مستمرة.

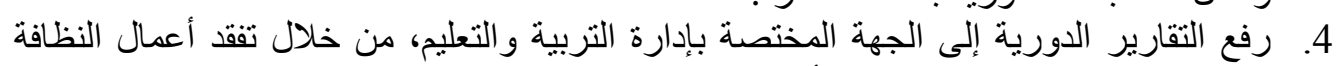

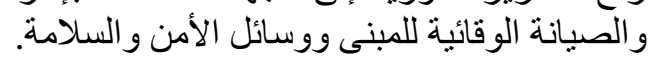

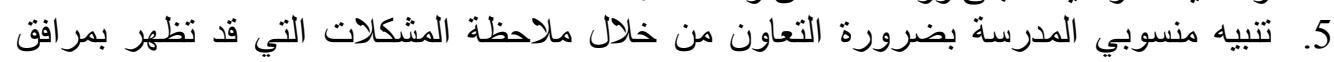

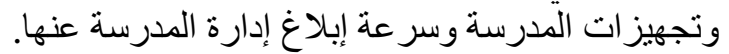

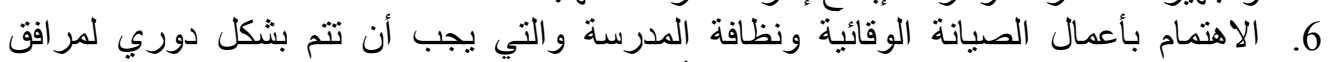

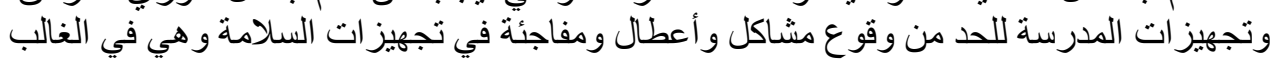
تعنمد على نتائج تفقد المبنى من قبل مستخدئ مندميه

\section{مهام ومسؤوليات إدارة التربية والتعليم بالمديرية:}

1. تحديد أعمال الصيانة العاجلة والصيانة الرئيسية (صيانة علاجية) اللازمة للمبنى عن طريق المعاينات.

2. المبدانية وتحليل التقارير الواردة من مديري ومدير ات المدارس وفرق الصيانة.

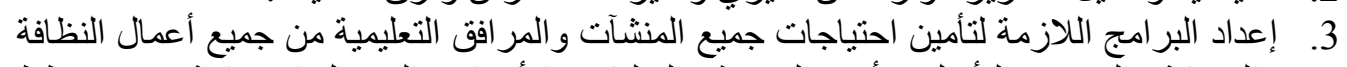

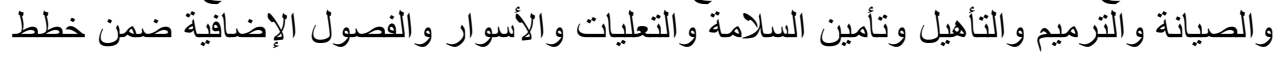

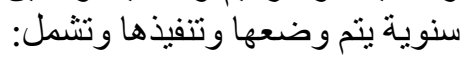
أـ المعاينات الميدانية لجميع المنشآت التعليمية لتحديد احتياجها من الأعمال المذكورة واتخاذ التهاذ

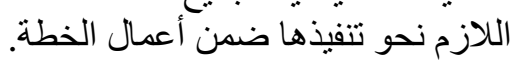
ب- وضع برنامج لفرق الصيانة من الفنبين للمرور بصفة أفئة دورية على المدارس لتنفيذ مهام صيانتها بمعدل أربع مر ات لكع لفرن مدرسة.

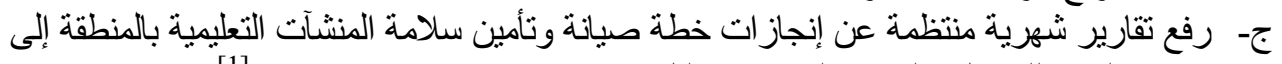

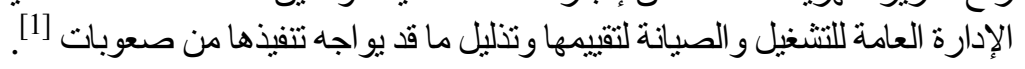

\section{مهام ومسؤوليات الإدارة العامة للتشغيل والصبانة بالمحافظة:}

1. إعداد ومتابعة تنفيذ خطط صيانة وترميم وتأهيل المباني والمرافق التعليمية بمختلف المناطق و المديريات و تقييم إنجاز اتها. 2. إعداد مشّاريع ميز انية أعمال الصيانة وانية والترميم و التأهيل والفصول الإضافية ور فعها لوزارة المالية

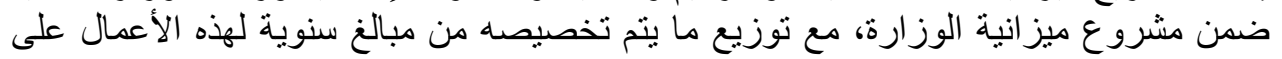

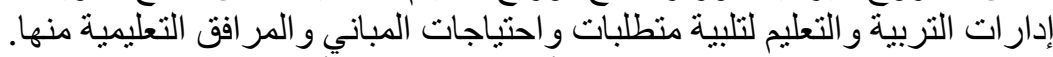

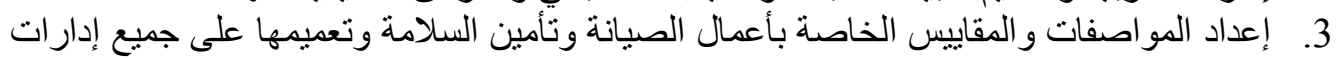

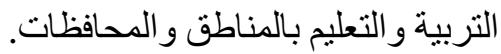

[1] [2] وزارة التربية و التعليم وكالة الوزارة للمباني، الصيانة وتحقيق السلامة في المباني التعليمية، المملكة العربية السعودية، 1429هـ.

Journal of Engineering Sciences, Assiut University, Faculty of Engineering, Vol. 41, No. 3, pp. 1212 - 1237, May, 2013, E-mail address: jes@aun.edu.eg 


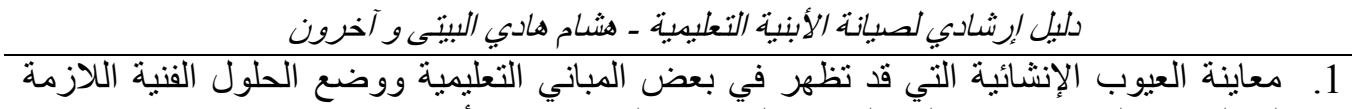

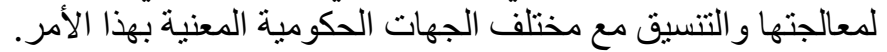

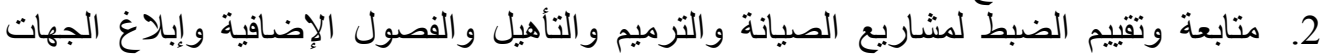

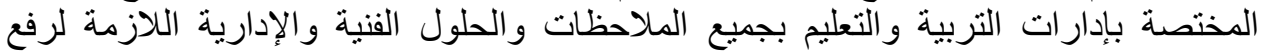

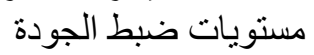
3. در اسة المشاكل التي يتم ملاحظة تكر ار ها في إدارات التربية و التعليم و إبلاغ هذه الإدار ات بالحلول

$$
\text { 3.3. } 3 \text { ـ المحور الثالث: الدعم المالي لأعمال الصبانة المدرسبية }
$$

يضم هذا المحور خطوتين، الخطوة الأولى تحديد مستويات الكلفة تبعا لأعمال الصيانة، والثانية تتعلق

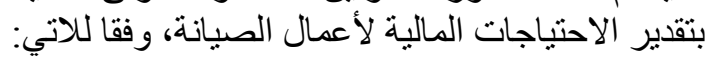

$$
\text { 1-3-3-3 ـ تحدبي مستويات الكلفة تبعا لأ عمال الصبانة: }
$$$$
\text { تنقسم كلفة أعمال الصيانة إلى ثناثة مستويات و هي: الصيات }
$$

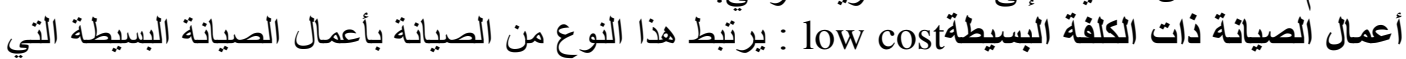

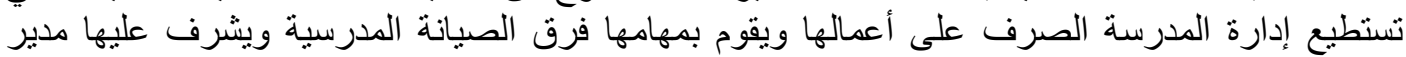

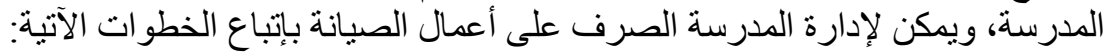

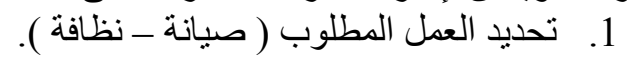

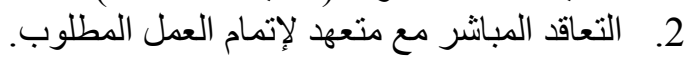
3.

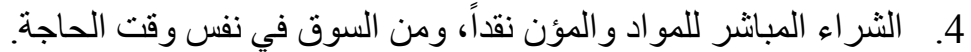

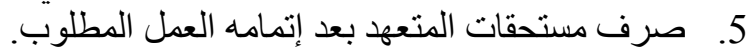

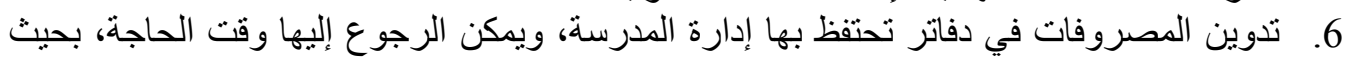

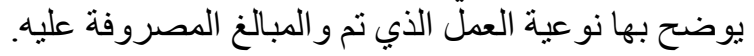

أعمال الصيانة ذات الكلفة المتوسطة Middle cost : يرتبط هذا النوع من الصيانة بأعمال الصيانة الوقائية

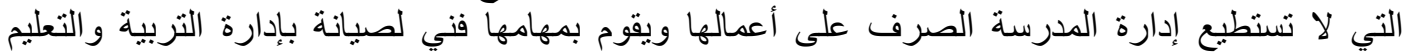
بالمديرية، ويشمل هذا النوع من الصيانة جميع أعمال الصيانة الوقائية من أعمال صحية ولئية وكهربائية ونجارة ودهان و إصلاح الأثاث المدرسي.

أعمال الصيانة ذات الكلفة العالية High cost : يرتبط هذا النوع من الصيانة بأعمال الصيانة الرئيسية التي التي الإني

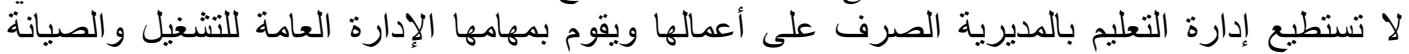

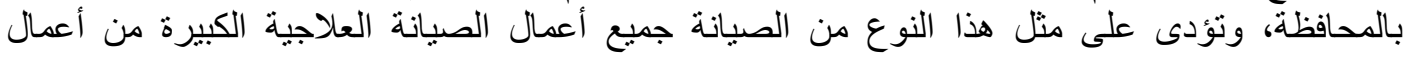

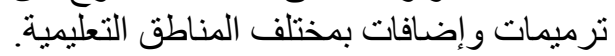

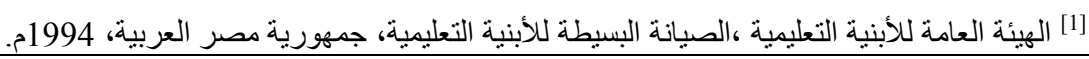
Journal of Engineering Sciences, Assiut University, Faculty of Engineering, Vol. 41, No. 3, pp. 1212 - 1237, May, 2013, E-mail address: jes@aun.edu.eg 


$$
\text { 2-3-3-3. تقدبر الاحتباجات المالية لأ عمال الصبانة الأبنية التعلبية ـ هشام هادي البيتى و آخرون }
$$

يرى الباحث أن يتم تحديد مبلغ معين يمكن السحب منه لتغطية أعمال الصيانة البسيطة ويمكن تخفيض هذا التها

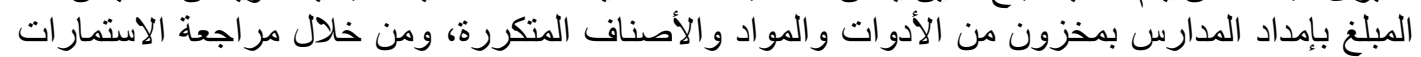

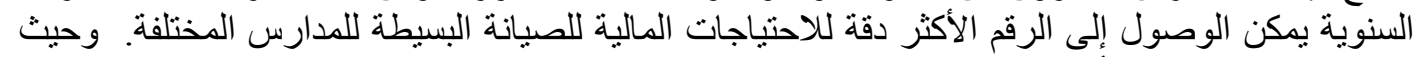

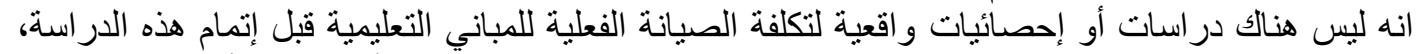

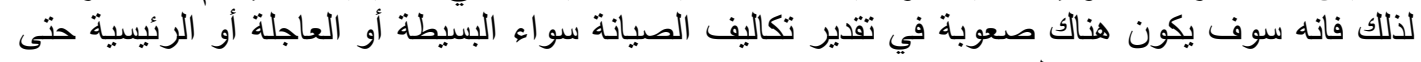

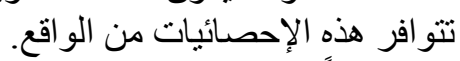

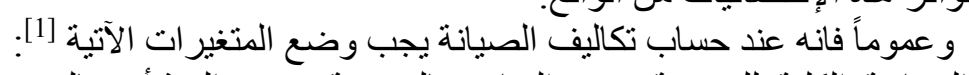

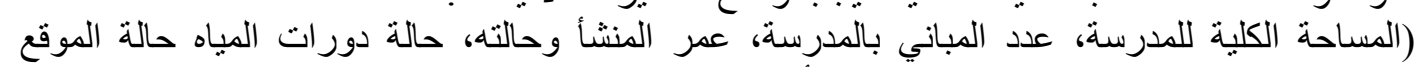

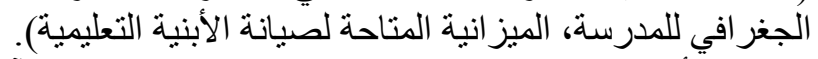

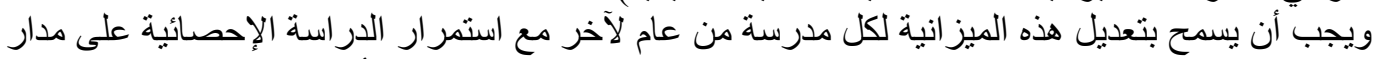

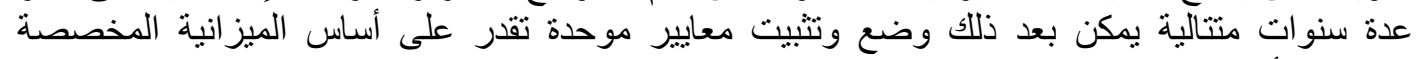
للمدارس بأنو اعها المختلفة مثلة بكن.

$$
\text { 3.3. } 4 \text { ـ المحور الرابع: البرنامج الزمني لتنفبذ أعمال الصبانة }
$$

يعنى هذا المحور بالجانب الزمني لتنفيذ أعمال الصيانة، ويتحدد البرنامج الزمني وفقاً للجدول التالي:

\begin{tabular}{|c|c|}
\hline برنامجج العمل & الإلزمنيج \\
\hline 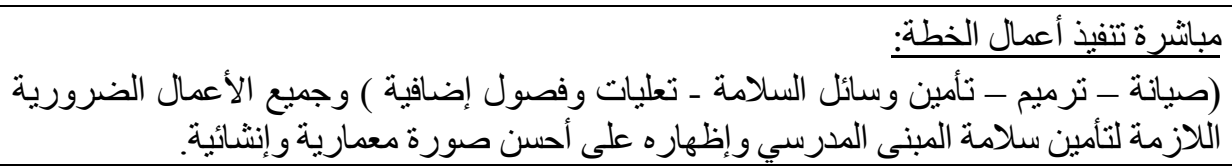 & 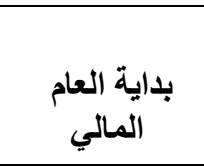 \\
\hline الاستمر ار في أعمال الصيانة ومرور فرق الصيانة على المباني المدرسية لتتفيذ الصيانة الوقائية. & إ جازة منتصف العام \\
\hline التركيز على صيانة أجهزة التهوية والتبريد بالمدارس بأعمال الخطة. & دخول فصل الصيف \\
\hline ا ـ ـ ترميئة المباني المدرسية للعام الدر اسي الجديد من خلال : أكبر عدد من المباني المدرسية المدرجة بخطة العام القادم. & بداية إجازة \\
\hline
\end{tabular}

جدول رقم (2): البرنامج الزمني لأعمال الصيانة المدرسية [1]

[2] وزارة التربية و التعليم بالمملكة العربية السعودية. 1429 هـ.مع عمل بعض التعديلات الخاصة بالفتر ات بما يتتاسب مع اليمن.

Journal of Engineering Sciences, Assiut University, Faculty of Engineering, Vol. 41, No. 3, pp. 1212 - 1237, May, 2013, E-mail address: jes@aun.edu.eg 


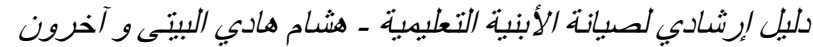

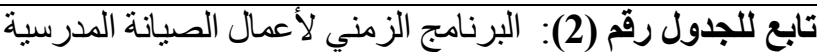

\begin{tabular}{|c|c|}
\hline برنامجج العمل & الزازئنامج \\
\hline 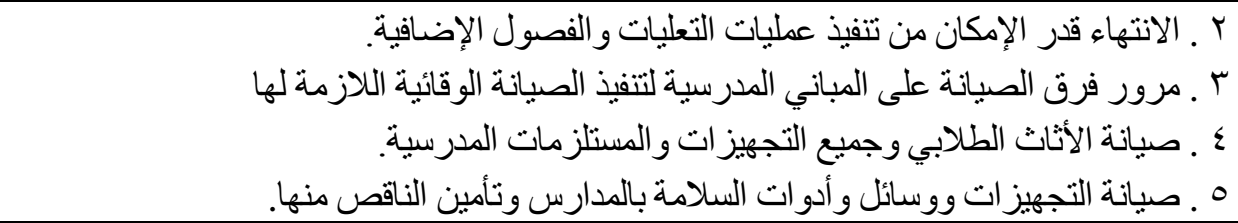 & بداية إجازة \\
\hline 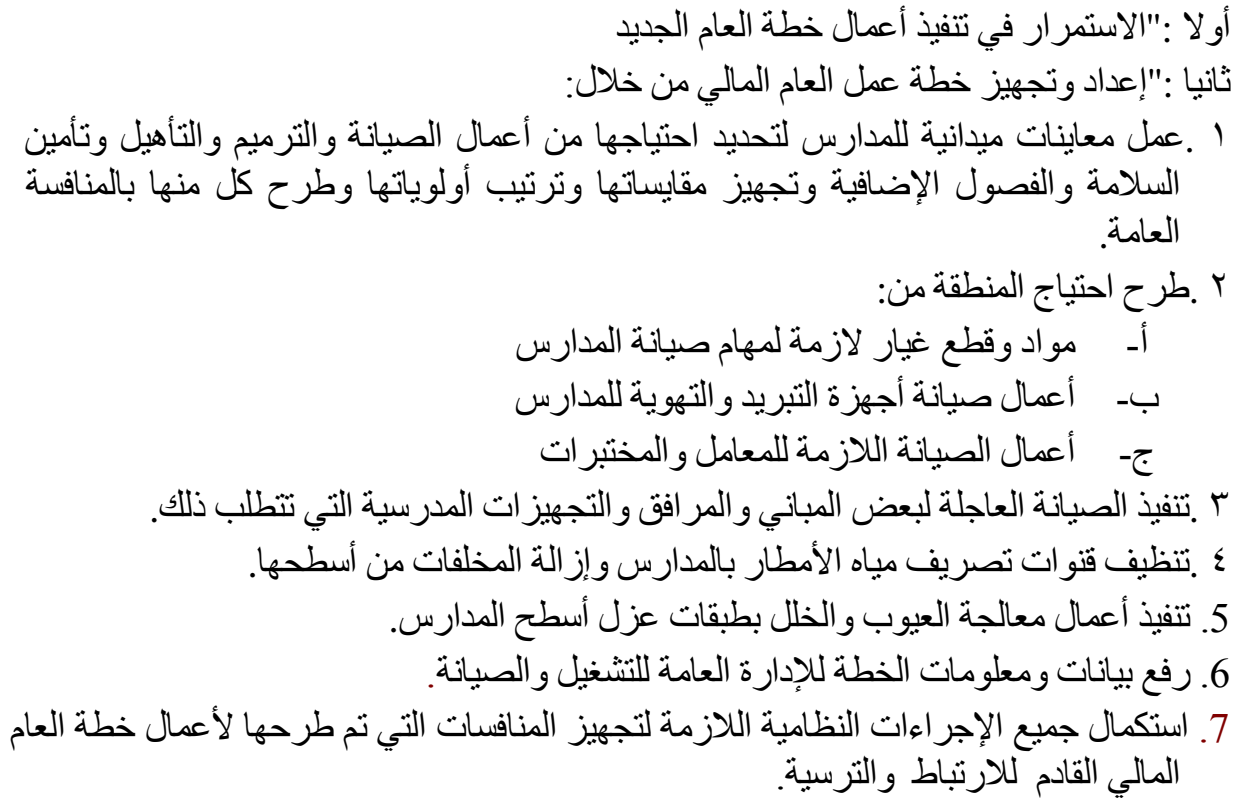 & 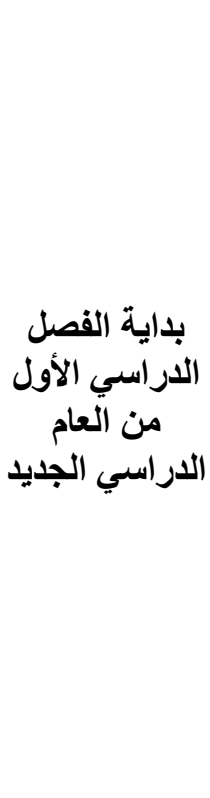 \\
\hline
\end{tabular}

(المحور الخامس: آلبة تنفبذ أعمال الصبانة

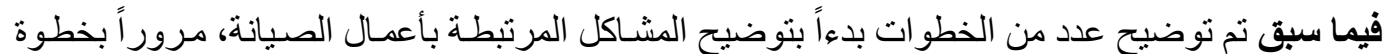

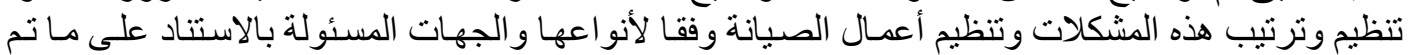

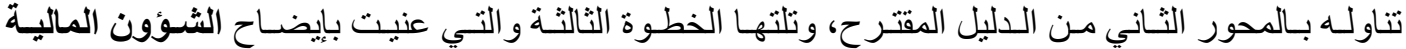

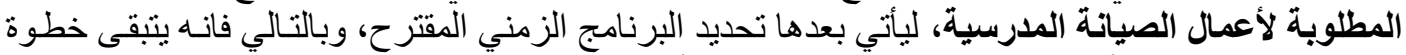

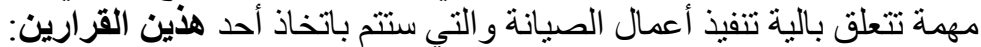

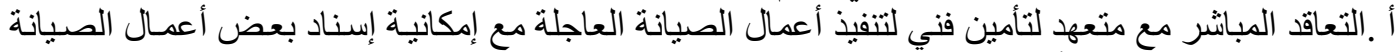

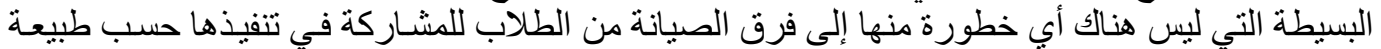

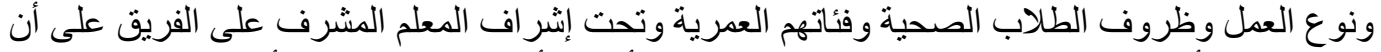

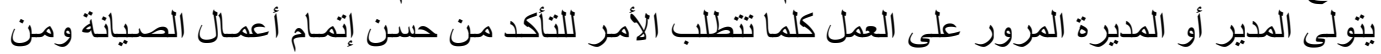
ضمنها أعمال الصيانة البسيطة التي يمكن للمدرسة تنفيذها.

Journal of Engineering Sciences, Assiut University, Faculty of Engineering, Vol. 41, No. 3, pp. 1212 - 1237, May, 2013,E-mail address: jes@aun.edu.eg 


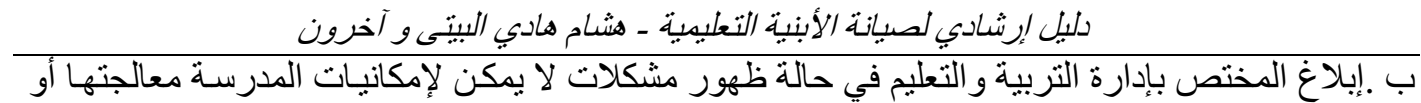

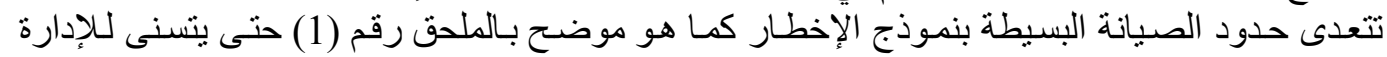

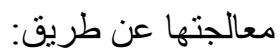
1. 2. إسنادها لمقاولين متخصصين (صيانة - ترميم - تأهيل).

$$
\text { } 1.5 .3 .3
$$

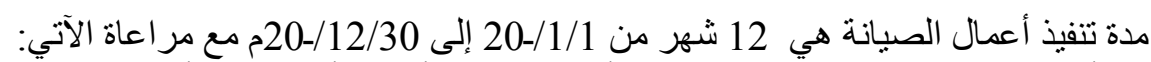

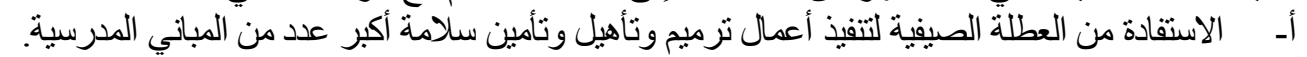

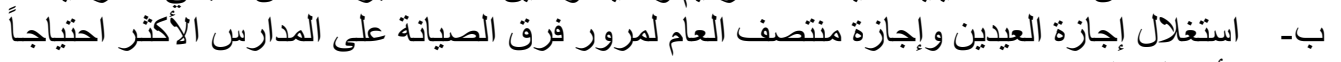
لأعمال الصيانة وتنفيذها.

\subsubsection{3}

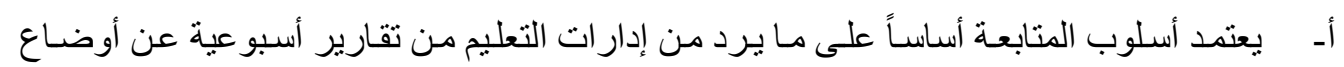

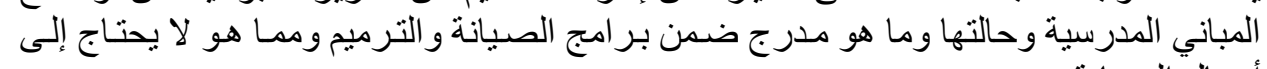
أعمال الصبانة المدربة.

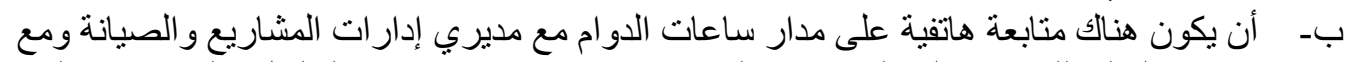

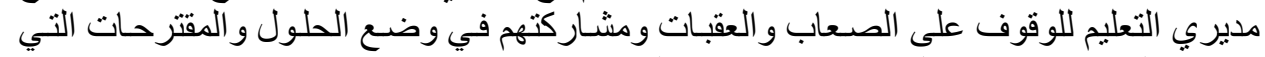

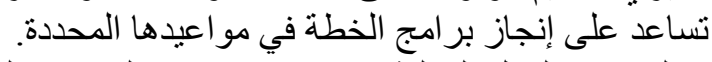

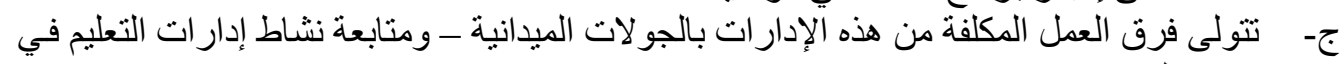
إنجاز التز امها.

4-3. المنظومة المقترحة لدلبل صبانة المبانسي المدرسبة:

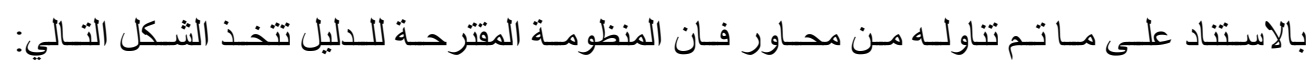

Journal of Engineering Sciences, Assiut University, Faculty of Engineering, Vol. 41, No. 3, pp. 1212 - 1237, May, 2013, E-mail address: jes@aun.edu.eg 
هشام هادى البيتى و آخرون - دليل إرشادي لصبانة الأبنبة التعليمبية

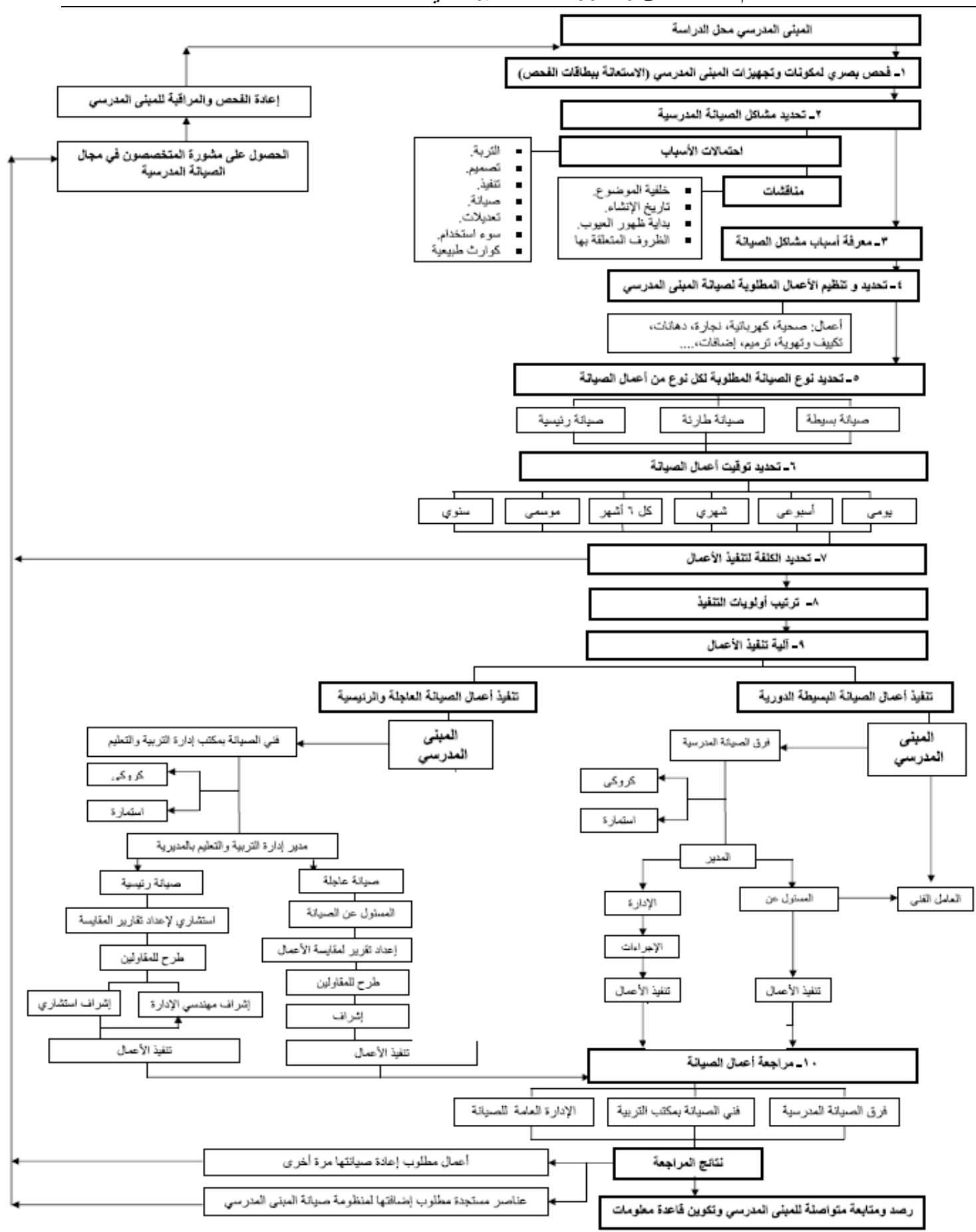

Journal of Engineering Sciences, Assiut University, Faculty of Engineering, Vol. 41, No. 3, pp. 1112 - 1237, May, 2013, E-mail address: jes@aun.edu.eg 
5.3

يتضـمن هذا الجزء اختبـار الدليل على إحدى مدارس التعليم الأساسـي بمدينـة المكلا بحضـرموت وسيتم تناولها وفق النقاط الآتية:

1-5-3 البطاقة التعربفية بالعبنة

\begin{tabular}{|c|c|c|c|}
\hline من الصف الر ابع إلى الصف & المرحلة التعليمية & مدرسة الجماهير لتعليم & اسم المدرسة \\
\hline 1830 طَالب & الطاقة الاستيعابية & مدينة المكلا- حضرموت & موقع المدرسة \\
\hline فترتين: صباحية ومسائية & عدد الفتر ات & 1963م & سنة التشغيل \\
\hline
\end{tabular}

بتتبع مر احل وخطو ات الدليل المقتر ح فانه تتحدد لدينا الخطو ات التالية:

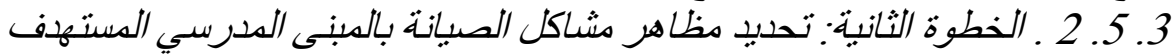
سيتم عرض مشاكل الصيانة بهذه المدرسة وفق الترتئ تحاني الآتي:

أ ألفراغات التعليهية والإدارية:

تتحدد مشاكل الصيانة بهذه الفرانئ اغات الات في الآتي:

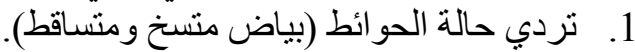

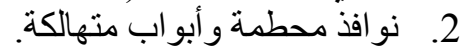

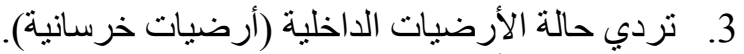

4. . تردي حالة الأثناث.

5. تردي حالة التجهيز ات الكهربائية.
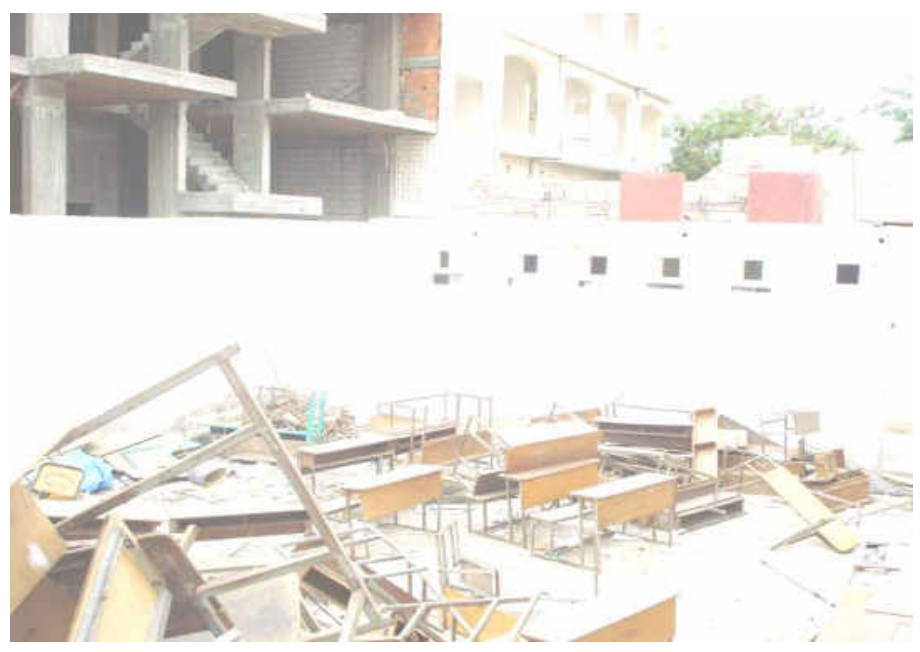

ب. دورات المباه والطرقات:

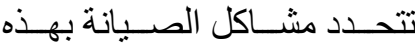

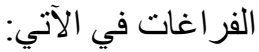

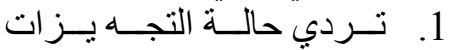

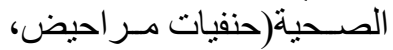
أحو اض، صفايات...) 2. طفح المجاري.

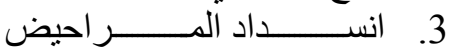

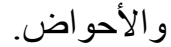
4. تردي حالة الطرقات (أرضيات خرسانية).

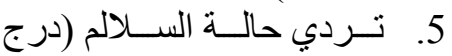
معدول بلياسة متهالكة).

شكل (2): صورة للأثاث المتهالك في الساحة المفتوحة المجاورة لكتلة الحمامات و المصلى 
هشام هادى البيتى و آخرون - دليل إرشادي لصيانة الأبنية التعليمية 3.5.3. 3 ـ الخطوة الثالثة: التعرف هادى الئى أسباب ظطهور مشاكل الصبيانة

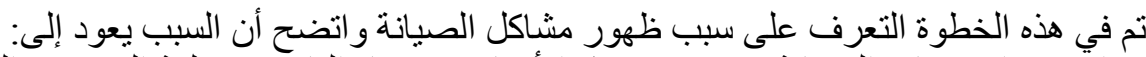

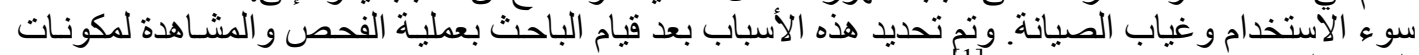
المبنى المدرسي في در اسة سابقة [1] 4. 4 ـ الخطوة الرابعة و الخامسة: تحديد وتنظيم المشاكل المرتبطة بالصيانة

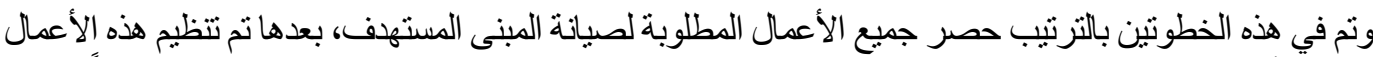
المرتبطة بأعمال الصيانة وفق نوع الصيانة والجهة المسئولة عنها، وقد ضم الجدول رقم (3) هذه الخطوتين وفقاً للاتي:

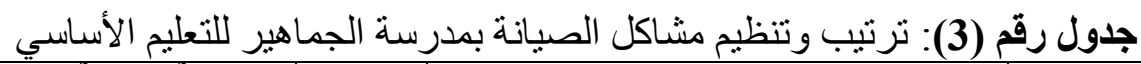

\begin{tabular}{|c|c|c|c|c|c|c|}
\hline \multicolumn{3}{|c|}{ الجهة المسئولة عن تَتفيذها } & & \multirow[b]{2}{*}{ مظاهر مشكلة الصيانة } & \multirow[b]{2}{*}{ العمل } & \multirow[b]{2}{*}{ العمل } \\
\hline الصبانة & بالإلفارة & 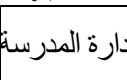 & الصيأنة & & & \\
\hline & & $\checkmark$ & بسيطة & انسداد الأحواض وسيفونات الصرف لدورة المياه & \multirow{5}{*}{ ل المياهات } & \multirow{5}{*}{ صحي } \\
\hline & $\checkmark$ & & طارئة & أنسداد المراحيض/دورات المياه & & \\
\hline & $\checkmark$ & & طارئة & تردي حالة مواسير صرف/تغذية & & \\
\hline & & $\checkmark$ & بسيطة & انسداد مز اريب صرف المطر & & \\
\hline & $\checkmark$ & & طارئة & طفح مجاري من غرف التفنتش & & \\
\hline & & $\checkmark$ & لمورية & انطفاء المصباح الكهربائي & \multirow{3}{*}{ كهربائي } & \multirow{3}{*}{ كهرباء } \\
\hline & & $\checkmark$ & دورية & وجود أثار حريق حول فتحات المخارج & & \\
\hline & $\checkmark$ & & لمورية & تهالك حالة المصباح/الدفاتيح & & \\
\hline & & $\checkmark$ & بسيطة & زجاج مكسور & \multirow{7}{*}{ وُشبابيات } & \multirow{7}{*}{ نجارة } \\
\hline & $\checkmark$ & & طارئة & تردي حالة الابواب (ابو اب متهالكة)/الابواب & & \\
\hline & & $\checkmark$ & بسيطة & صعوبة إغلاق وفتح الابواب & & \\
\hline & & & بسيطة & تردي حالة الدو لاب بمكاتب الإدارة والمدرسين & & \\
\hline & $\checkmark$ & & طارئة & تردي حالة الآثاث (طاولة وكرسي) وحالة السبورة & & \\
\hline & $\checkmark$ & & طارئة & وجود اثثاث تالف متكس بفناء الكدرسة & & \\
\hline & & $\checkmark$ & بسيطة & ظهور صدا بالاجزاء المعنية داخل او خارج & & \\
\hline \multirow{2}{*}{$\checkmark$} & & & \multirow{2}{*}{ رئيسية } & تردي حالة الحوائط تشققات/ رشح مياه/شروخ & حو حائط & \multirow{2}{*}{ دهاتات } \\
\hline & & & & 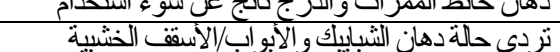 & 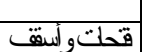 & \\
\hline \multirow{4}{*}{$\checkmark$} & & & \multirow{4}{*}{ رئيسية } & 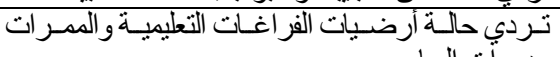 & \multirow{4}{*}{ تأسبس فكلـادة } & \multirow{4}{*}{ ت ترئلات } \\
\hline & & & & تردي حالة واجهات المبنى & & \\
\hline & & & & شروخ باركان المبنى & & \\
\hline & & & & تسريب مياه الأمطار من أسطح المبنى & & \\
\hline
\end{tabular}

[1] البيتي،هثام هادي، " دراسة تحليلية عن تصميم مباني التعليم الأساسي بالدن اليمنية"هدينة المكلا ككر اسة حالة" ، ماجستير، جامعة أسيوط، 2009م.

Journal of Engineering Sciences, Assiut University, Faculty of Engineering, Vol. 41, No. 3, pp. 1112 - 1237, May, 2013,E-mail address: jes@aun.edu.eg 


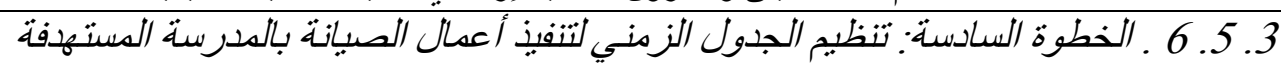

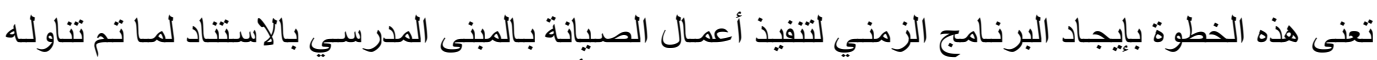

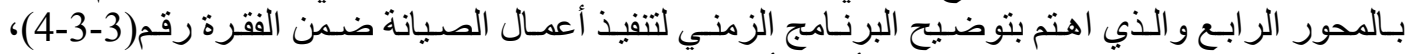

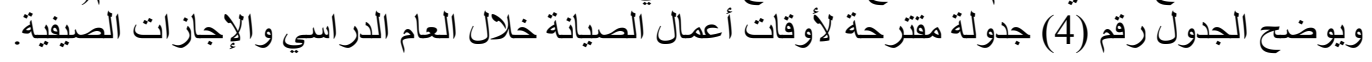

\begin{tabular}{|c|c|c|c|c|c|c|c|c|c|c|c|c|c|c|}
\hline \multicolumn{12}{|c|}{ أثثـــــهر السنـــــــة } & \multirow{2}{*}{ بنود الأعمال لمعالجة مشاكل الصيانة } & \multirow{2}{*}{ الأعمال } & \multirow{2}{*}{ الصياتة } \\
\hline 12 & 11 & 10 & 9 & 8 & 7 & 6 & 5 & 4 & 3 & 2 & 1 & & & \\
\hline & & & & & & & & & & 2 & & 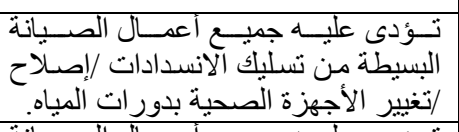 & 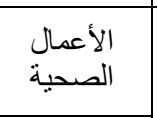 & \multirow{5}{*}{ 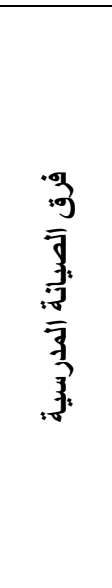 } \\
\hline & & & & & & & & & & & & 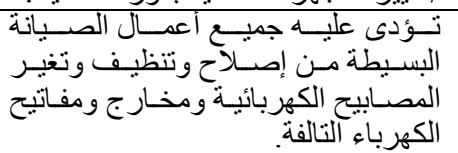 & الكهربائية - الأعمال & \\
\hline & & & & & & & & & & & & 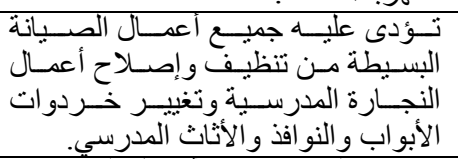 & 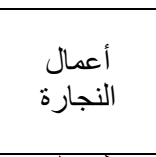 & \\
\hline & & & & & & & & & & & & 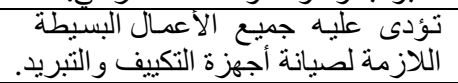 & \multirow{2}{*}{ 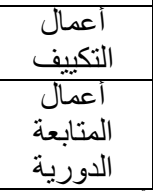 } & \\
\hline & & & & & & & & & & & & 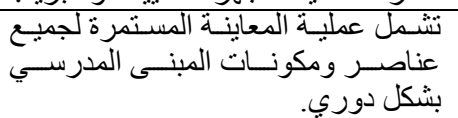 & & \\
\hline \multicolumn{15}{|c|}{ 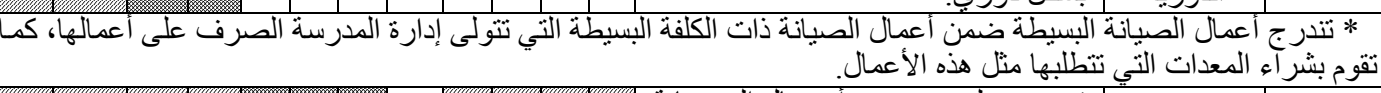 } \\
\hline & & & & & & & & & & & & 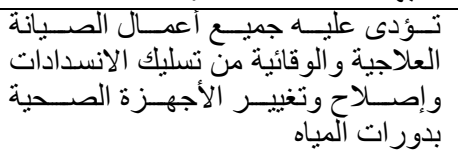 & 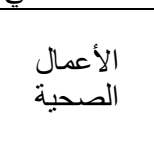 & \multirow{5}{*}{ 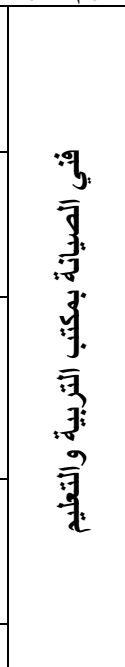 } \\
\hline & & & & & & & & & & & & 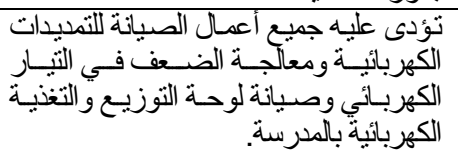 & الكهربائية & \\
\hline & & & & & & & & & & & & 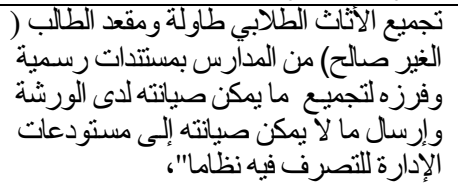 & 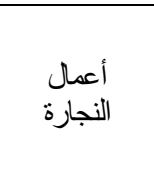 & \\
\hline & & & & & & & & & & & & 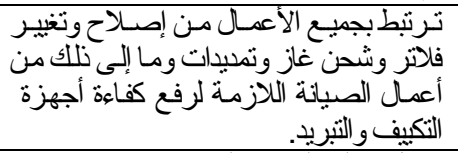 & تكييف & \\
\hline & & & & & & & & & & & & تثتمل عملية المعاينة الدورية & المتلجعة للورية & \\
\hline \multicolumn{14}{|c|}{ | } & \\
\hline
\end{tabular}

Journal of Engineering Sciences, Assiut University, Faculty of Engineering, Vol. 41, No. 3, pp. 1112 - 1237, May, 2013, E-mail address: jes@aun.edu.eg 
هشام هادى البيتى و آخرون - دليل إرشادي لصيانة الأبنية التعليمية

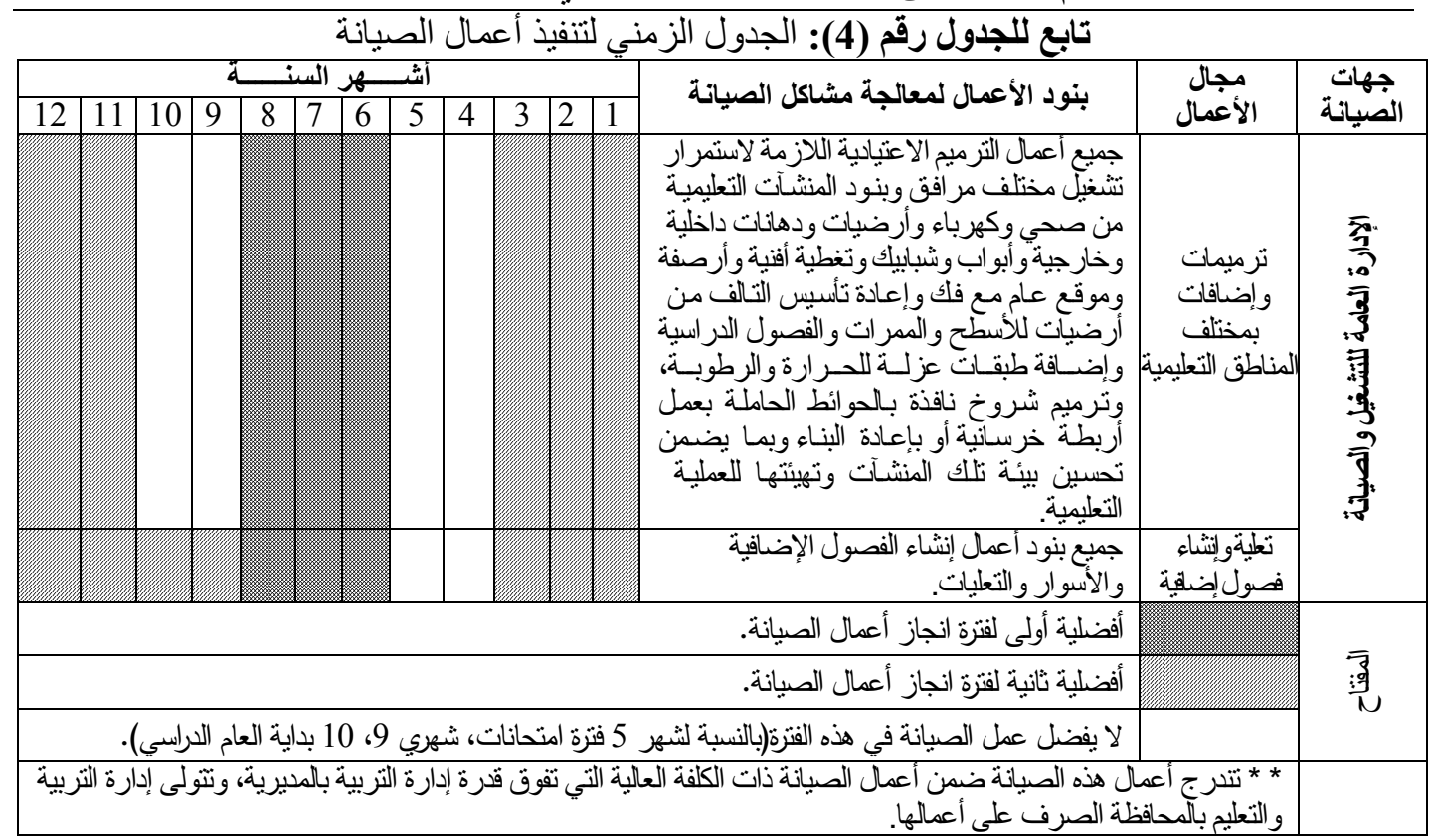

$$
7.5 .3 \text { ـ الخطوة السابعة: تحدبي كلفة أعمال الصبانة }
$$

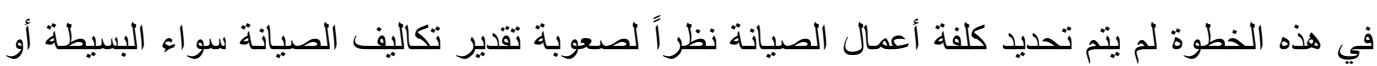
العاجلة أو الرئيسية حتى تتو افر الإحصائيات الو اقعية.

$$
\text { 8-5-3 الخطوة الثامنة: ترتبيب أولويات التنفيذ }
$$

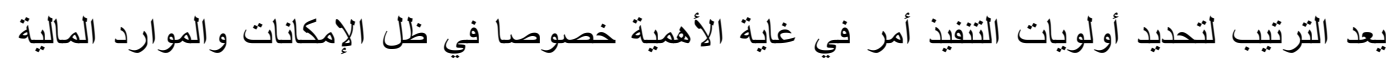

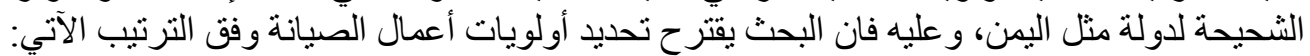

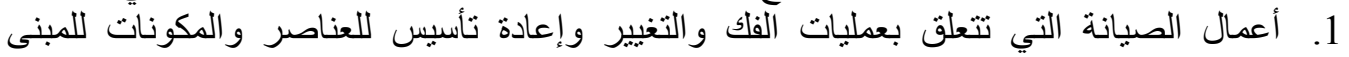

$$
\begin{aligned}
& \text { 2. } \\
& \text { 3. أعمال الصيانة التي تختص بأعمال التصال النجارة. }
\end{aligned}
$$

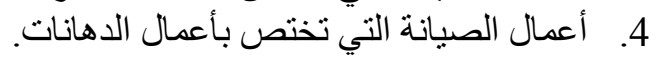

$$
\begin{aligned}
& \text { 5. أعمال الصيانة التي تختص بأعمال الكهربائية. } \\
& 9.5 .3 \text { ـ الخطوة التاسعة: آلبة تنفيذ أعمال الصبانة }
\end{aligned}
$$

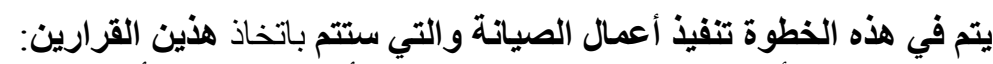

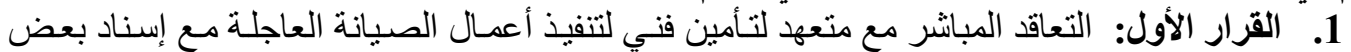

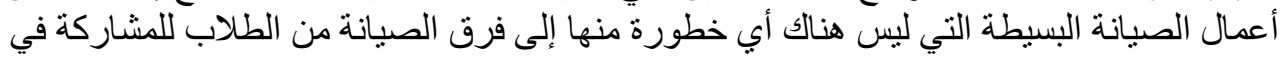

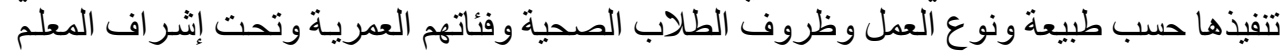




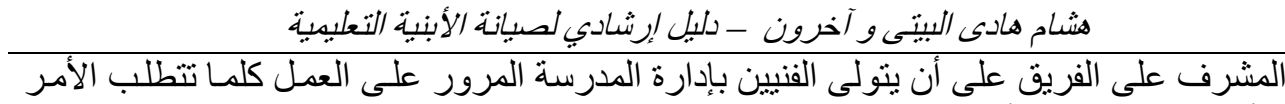

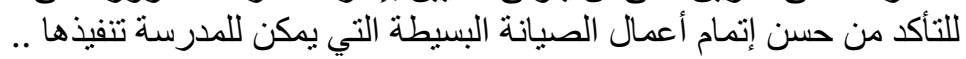

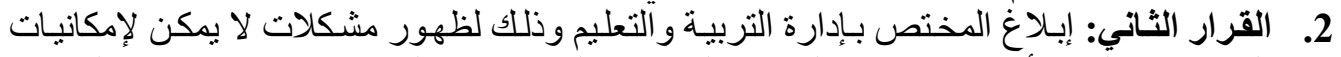

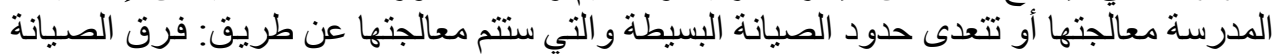

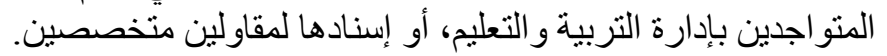

$$
\text { 10.5 } 10.5
$$

يتطلب مر اجعة أعمال الصبانة التي تم تنفيذها وذلك بعد اكتمال أعمال الصيانة للمبنى المدرسي المستهدف

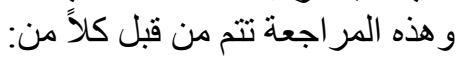

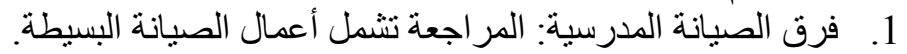

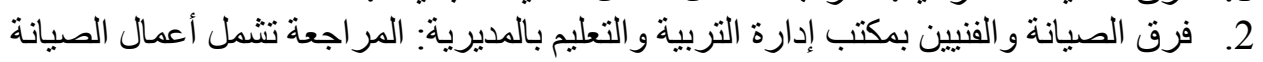

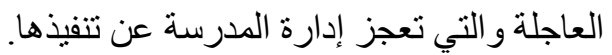
3. الإدارة العامةً للصيانة: المر اجعة تشمل العمارة العمال الصيانة الرئيسية التي تفوق قدرة الفنبين بمكتب إدارة التربية و التعليم.

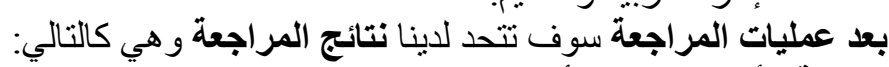

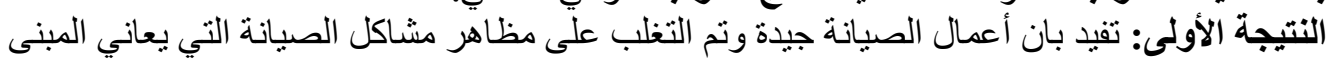

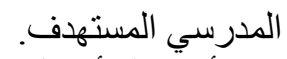
النتيجة الثاتية: تفيد بأن هناك أعمال مطلوب إلتوف إعادة صيانتها مرة أخرى.

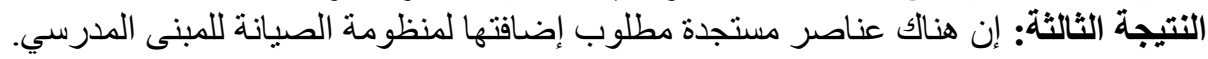

\section{خلاصة التجربة:}

تلخصت تجربة الدليل بإمكانية استخدامه على إحدى مدارس التعليم الأساسي بمدينة المكلا بحضرموت

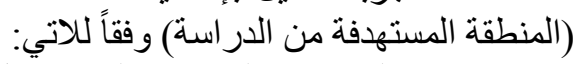

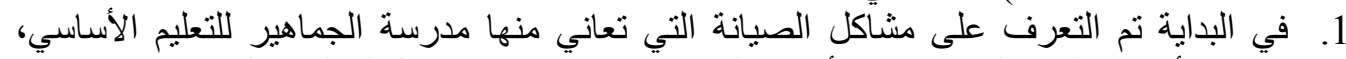

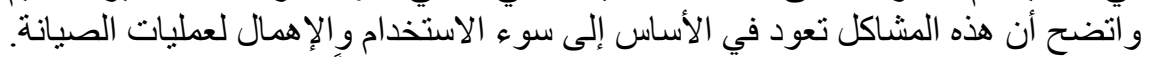

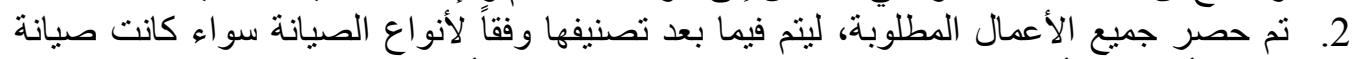
بسيطة أو عاجلة أو رئيسية وتحديد الجهات المسئولة عن هذه الأعمال.

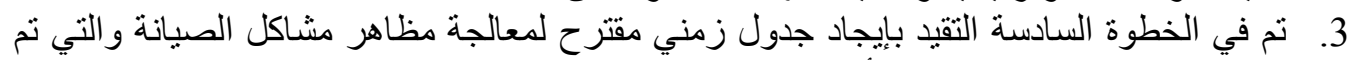

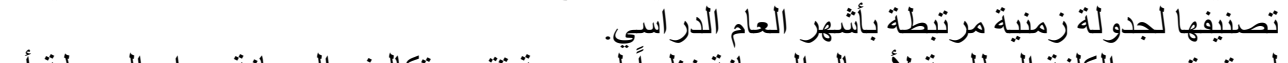

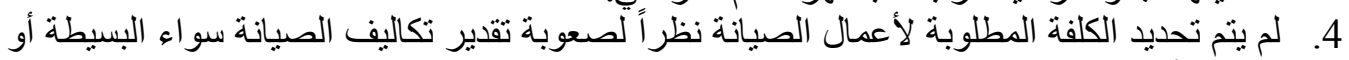
العاجلة أو الرئيسية لعدم توفر الإحصائيات الو المعية.

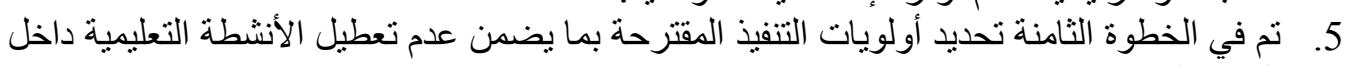
المبنى المدرسي. 6. الانتقال إلى الخطوة التاسعة للتعرف على آلى آلية تنفيذ أعمال الصيانة.

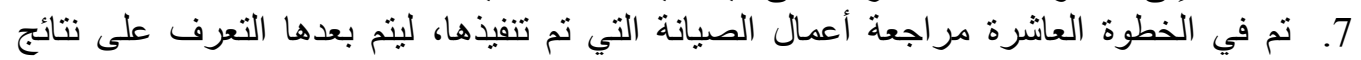
المر اجعة. 8. في حالة عدم التخلب على مشاكل الصيانة أو ظهور عناصر مستجدة مطلوب إضافتها لمنظومة الصيانة فانه يتعين الاستعانة بخبر اء متخصصين في مجال الصيانة المدرسية.

Journal of Engineering Sciences, Assiut University, Faculty of Engineering, Vol. 41, No. 3, pp. 1112 - 1237, May, 2013,E-mail address: jes@aun.edu.eg 
هشام هادى البيتى و آخرون - دليل إرشادي لصيانة الأبنية التعليمية

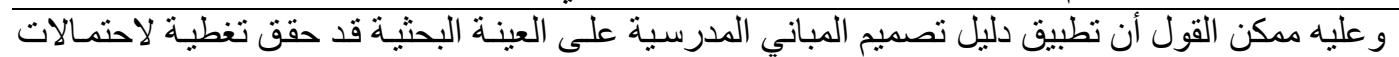

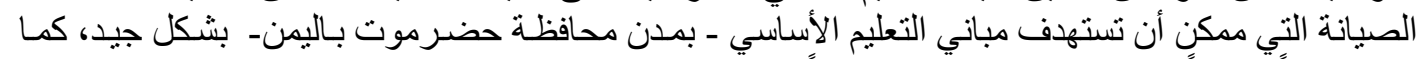

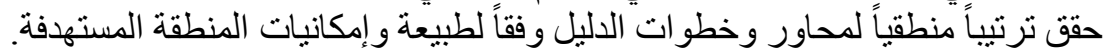

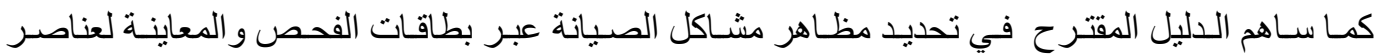

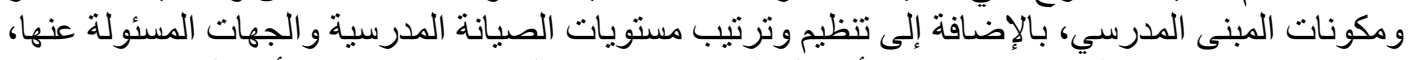

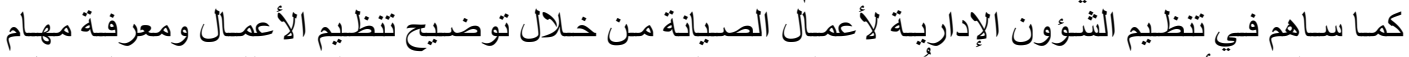

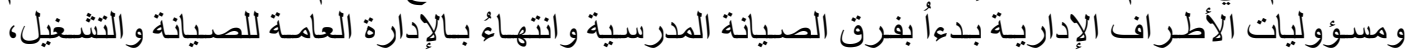

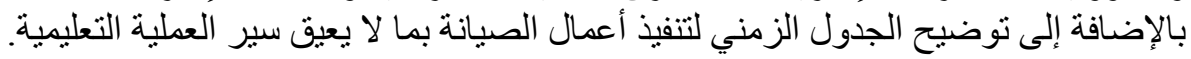

4. النتائج والتوصيات

$$
1.4
$$

1. تم التوصل إلى دليل مقترح لصيانة مباني التعليم الأساسي بمدن محافظة حضرموت باليمن لإمكانيـة

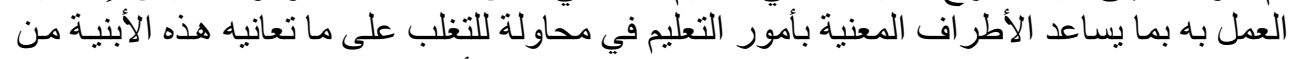

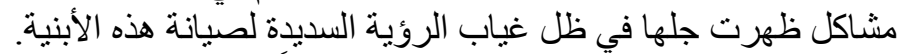

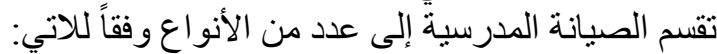

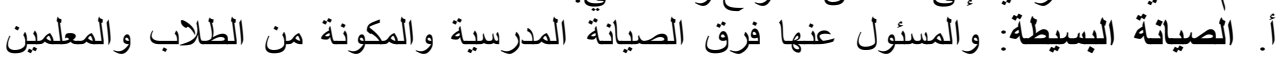
وبإثر اف من مدير المدرسة.

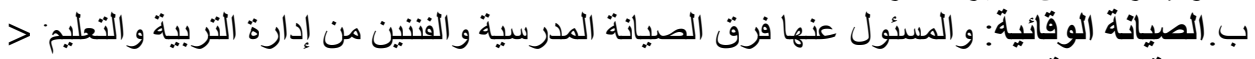

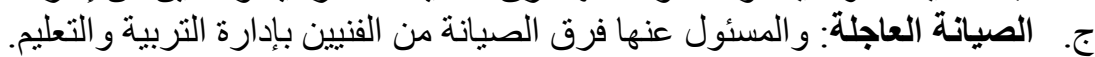

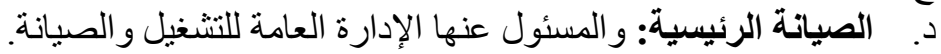

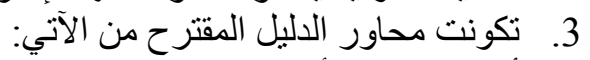

المحور الأول: عنى هذا المحور بتحديد وتنظيم وترتيب مستويات الصنيات الصيانة المدرسية والجهات

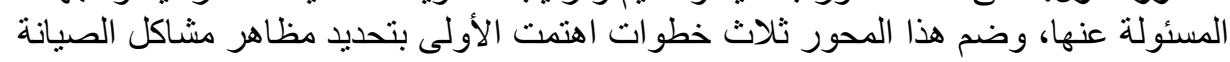

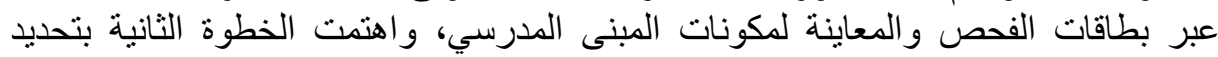

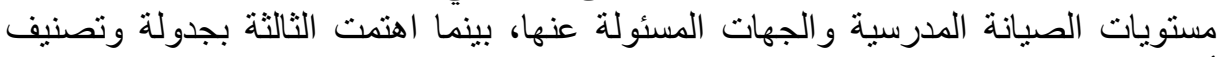
أعمال الصيانة.

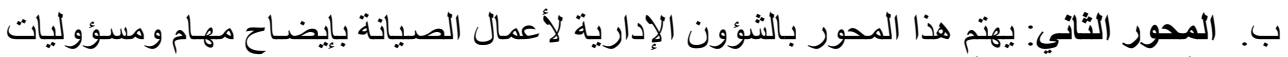

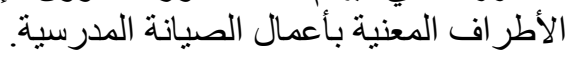

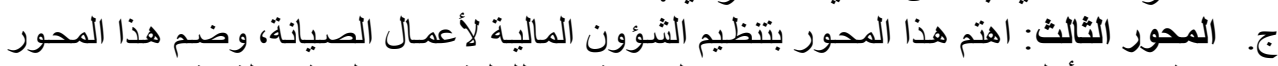

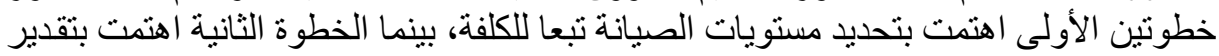

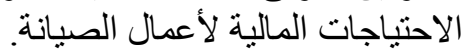

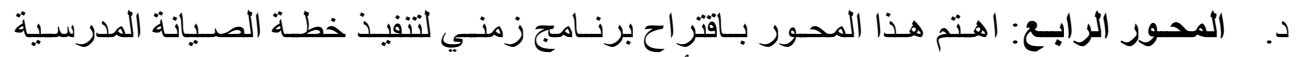

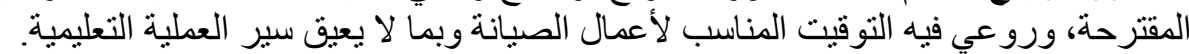

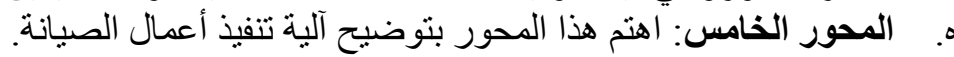

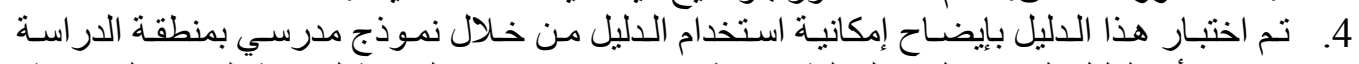
و اتضح أن الدليل الذي تم التوصل إلية قد غطى جميع الاحتمالات الممكنة لصيانة المباني المدرسية. 
1. التحول إلى السياسـات اللامركزية للانتقال إلى إعطاء الصـلاحيات الماليـة لإدار ات التعليم تسنطيع

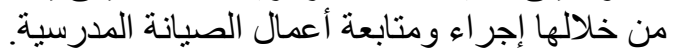

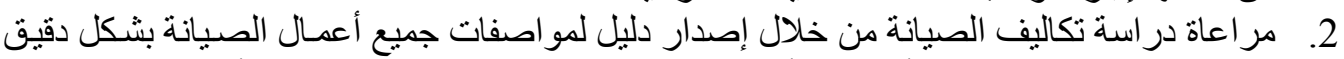

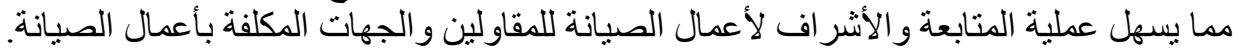

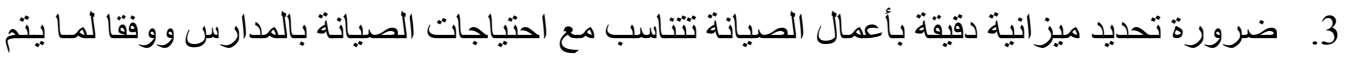

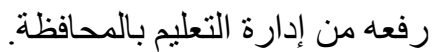

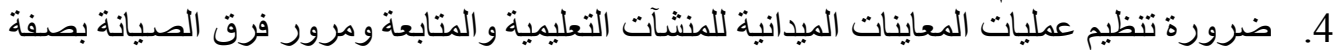

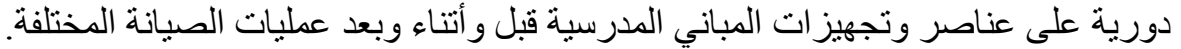

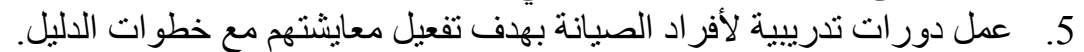

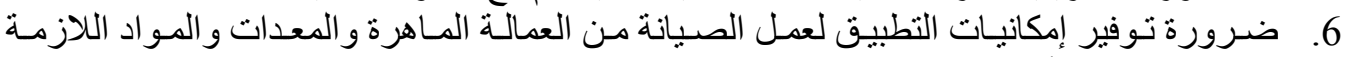

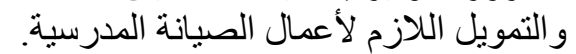
7.

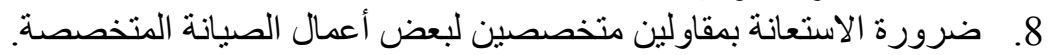

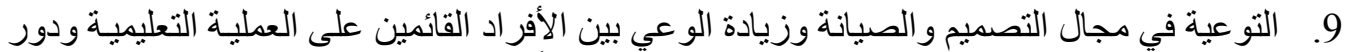

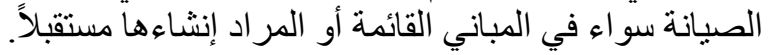

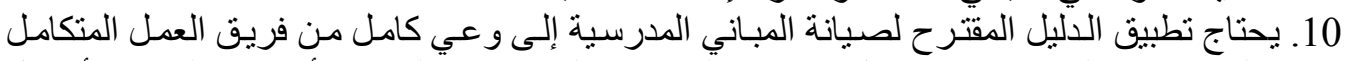

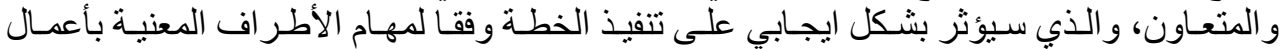

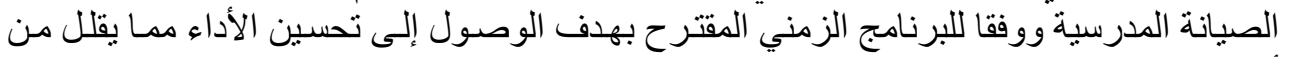
أعمال الصيانة ويقلل بالتالي من كلفتها.

5. الملاحق:

ملحق رقم(1): نموذج من بطاقات الفحص و المعاينة و التفتيش الدوري لأعمال الصيانة

\begin{tabular}{|c|c|c|c|c|c|}
\hline \multirow{3}{*}{\multicolumn{2}{|c|}{ 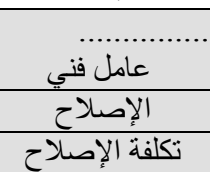 }} & \multicolumn{2}{|c|}{ ناريخ المعاينة:. } & القائم بالمعاينة: ..................... & 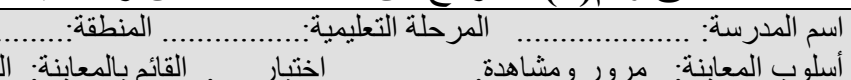 \\
\hline & & \multirow{3}{*}{ الفراغ } & & \multirow{3}{*}{ نعم } & \multirow{3}{*}{ 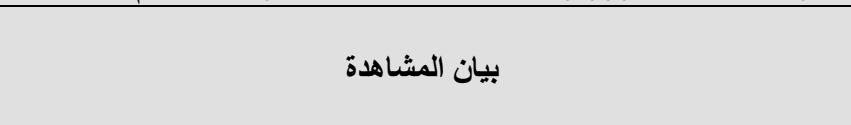 } \\
\hline & & & & & \\
\hline \multirow[t]{15}{*}{ عمالة } & مهمات & & $y$ & & \\
\hline & & & & & 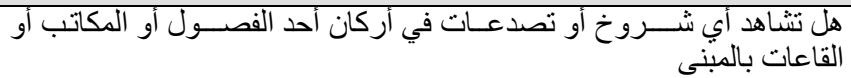 \\
\hline & & & & & هل تشاهد اب شروخ مائلة في الجدران \\
\hline & & & & & هل تثاهد ظهور حديد تسليح بالأسقف أو الكمر ات أو الأعمدة \\
\hline & & & & & هل توجد أجز اء هابطة حول المبنى أو داخل المبنى \\
\hline & & & & & هل يوجد تساقط بلياسة الحو ائط \\
\hline & & & & & هل يوجد تساقط ببلاط دور ات المياه \\
\hline & & & & & هل يوجد تساقط بالدهانات الخارجية \\
\hline & & & & & هل يوجد تساقط بالدهانات الداخلية للحو ائط ـ للأسقف \\
\hline & & & & & هل يوجد رشح بأسقف فصول الدور الاخخير \\
\hline & & & & & هل يوجد رشح بأسق دور ات المياه \\
\hline & & & & & هل يوجد تسرب للمياه من فو اصل التمدد \\
\hline & & & & & هل يوجد انسداد في مجاري صرف المطر بالسطح \\
\hline & & & & & هل يوجد طفح للمياه من الخزان العلوي/الخزان الآرضي \\
\hline & & & & & هل يوجد انسداد في احد دورات المياه (المر احيض) \\
\hline
\end{tabular}

Journal of Engineering Sciences, Assiut University, Faculty of Engineering, Vol. 41, No. 3, pp. 1112 - 1237, May, 2013, E-mail address: jes@aun.edu.eg 
هشام هادى البيتى و آخرون - دليل إرشادي لصيانة الأبنية التعليمية

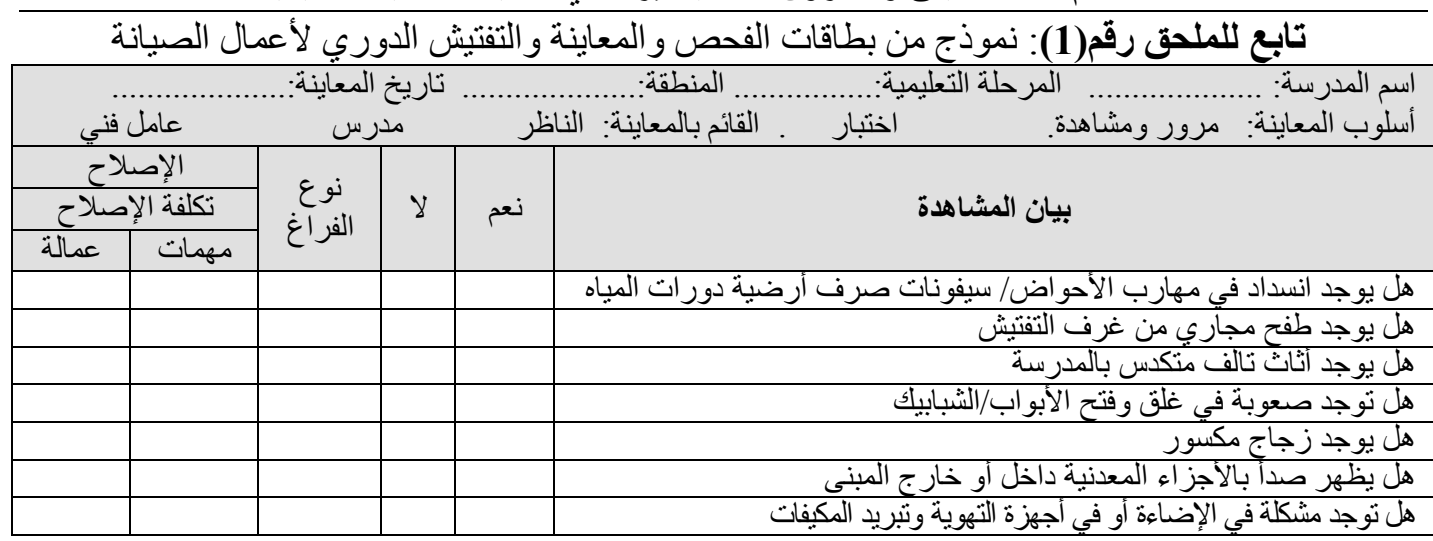

ملحق رقم(2): نموذج إبلاغ من مديري المدارس و الذي برفع لإدارة التعليم بالمحافظة

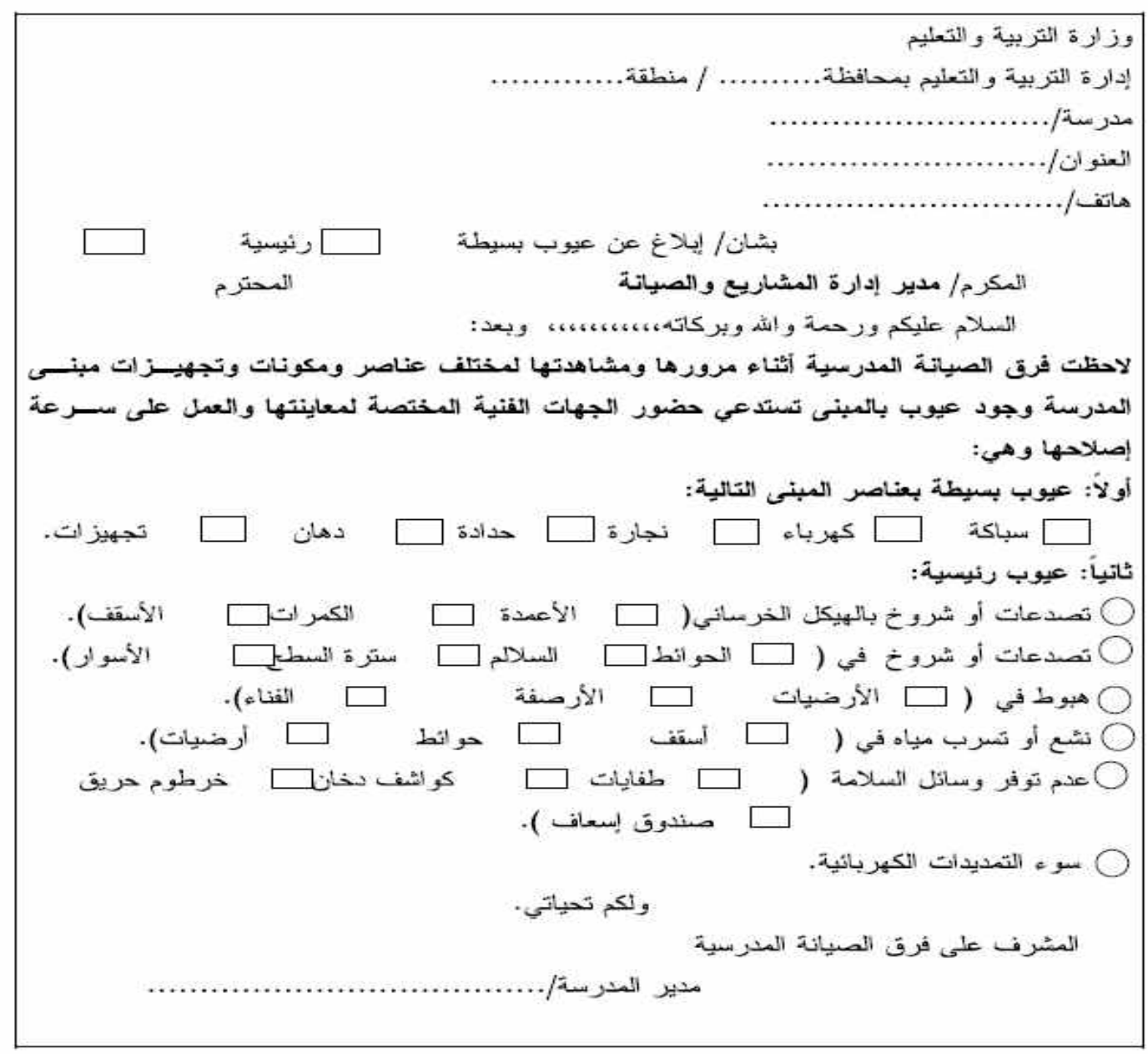

Journal of Engineering Sciences, Assiut University, Faculty of Engineering, Vol. 41, No. 3, pp. 1112 - 1237, May, 2013, E-mail address: jes@aun.edu.eg 


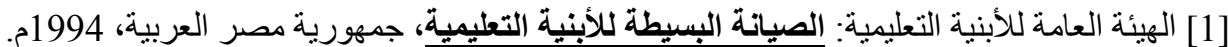

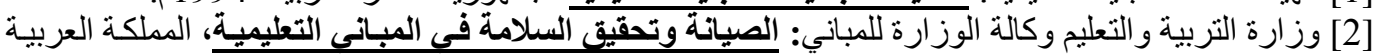

[3] المو اصفات القياسية المصرية (م ق م و وبr ) :المصطلحات الخاصة بالصيانة الوقائية والتصحيحية للمنشآت

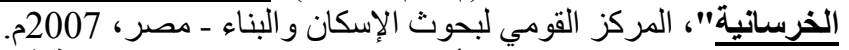

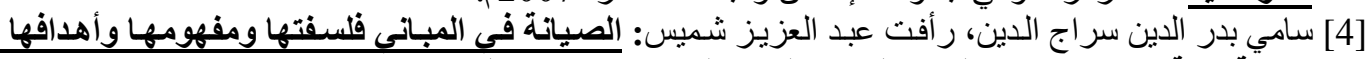

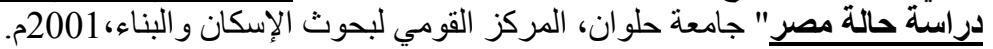

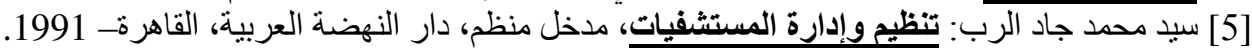

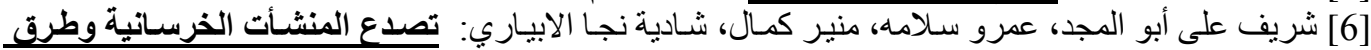

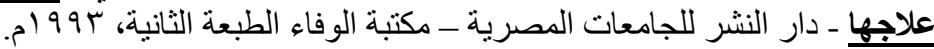

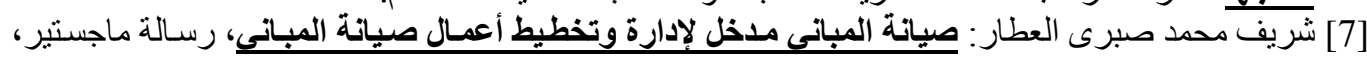

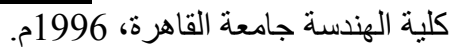

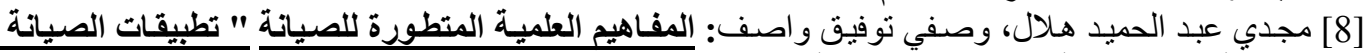

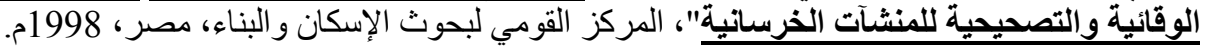

[9] Barrie chanter \& Peter swallow; Building maintenance management , Blackwell science, oxford, London ,1996.

[10] Mohmoud M.Idris; Some Factores Affecting Maintenance of Building in U.F.E, Technical article, Alarn Albena, issue 1983.

[11] Terry Wireman; Preventive Maintenance, Virginia Reston Pub. Co. - 1984.

[12] S. Ronald; Hospitals Al ministration, New York, 1991.

[13] Maynard ; How to manage maintenance Harvard , Bussiness Review 1995.

\title{
Guide for Maintenance of Educational Buildings "Elementary Education Buildings in Hadramout cities as a Case Study"
}
H. H. Albeity.
M. M. Radwan
M. A. Eid
M. A. Yosef

\begin{abstract}
The Preservation of Educational Buildings and their sustainable maintenance and renewal is of great importance. these buildings represent a vital role in the development of the society. The aim of this study is to provide a pilot manual for the Maintenance of the Educational Buildings.

The Study address the following points:

1 - The Introduction: includes (Problem, Objective, Methodology of the Study).

2 - Theoretical approach; Definition of the Concept of Maintenance, as addressed in previous studies. types of Maintenance, the most important activities associated with the Maintenance in Educational Buildings, organizational aspects of the technical and Administrative Maintenance. 3 - Manual for Maintenance in School Buildings and how to be used.

4 - Results and recommendations.
\end{abstract}

Journal of Engineering Sciences, Assiut University, Faculty of Engineering, Vol. 41, No. 3, pp. 1112 - 1237, May, 2013,E-mail address: jes@aun.edu.eg 